\title{
Methods to homogenize electrochemical concentration cell (ECC) ozonesonde measurements across changes in sensing solution concentration or ozonesonde manufacturer
}

\author{
Terry Deshler ${ }^{1}$, Rene Stübi ${ }^{2}$, Francis J. Schmidlin ${ }^{3}$, Jennifer L. Mercer ${ }^{1, a}$, Herman G. J. Smit ${ }^{4}$, Bryan J. Johnson ${ }^{5}$, \\ Rigel Kivi ${ }^{6}$, and Bruno Nardi ${ }^{1,7}$ \\ ${ }^{1}$ Department of Atmospheric Science, University of Wyoming, Laramie, Wyoming, USA \\ ${ }^{2}$ Meteo Swiss, Payerne, Switzerland \\ ${ }^{3}$ NASA Goddard Space Flight Center, Greenbelt, Maryland, USA \\ ${ }^{4}$ Forschungszentrum Jülich GmbH, Institute of Energy and Climate Research: Troposphere, Jülich, Germany \\ ${ }^{5}$ National Oceanic and Atmospheric Administration, Boulder, Colorado, USA \\ ${ }^{6}$ Finnish Meteorological Institute, Arctic Research, Sodankylä, Finland \\ ${ }^{7}$ Nardi Scientific, LLC, Denver, Colorado, USA \\ ${ }^{a}$ now at: National Science Foundation, Geosciences Directorate, Division of Polar Programs, Arlington, Virginia, USA
}

Correspondence to: Terry Deshler (deshler@uwyo.edu)

Received: 21 December 2016 - Discussion started: 2 January 2017

Revised: 5 April 2017 - Accepted: 15 April 2017 - Published: 7 June 2017

\begin{abstract}
Ozone plays a significant role in the chemical and radiative state of the atmosphere. For this reason there are many instruments used to measure ozone from the ground, from space, and from balloons. Balloon-borne electrochemical cell ozonesondes provide some of the best measurements of the ozone profile up to the mid-stratosphere, providing high vertical resolution, high precision, and a wide geographic distribution. From the mid-1990s to the late 2000s the consistency of long-term records from balloon-borne ozonesondes has been compromised by differences in manufacturers, Science Pump (SP) and ENSCI (EN), and differences in recommended sensor solution concentrations, $1.0 \%$ potassium iodide (KI) and the one-half dilution: $0.5 \%$. To investigate these differences, a number of organizations have independently undertaken comparisons of the various ozonesonde types and solution concentrations, resulting in 197 ozonesonde comparison profiles. The goal of this study is to derive transfer functions to allow measurements outside of standard recommendations, for sensor composition and ozonesonde type, to be converted to a standard measurement and thus homogenize the data to the expected accuracy of $5 \%(10 \%)$ in the stratosphere (troposphere). Subsets of these data have been analyzed previously and intermediate transfer functions derived. Here all the comparison data
\end{abstract}

are analyzed to compare (1) differences in sensor solution composition for a single ozonesonde type, (2) differences in ozonesonde type for a single sensor solution composition, and (3) the World Meteorological Organization's (WMO) and manufacturers' recommendations of $1.0 \% \mathrm{KI}$ solution for Science Pump and $0.5 \%$ KI for ENSCI. From the recommendations it is clear that ENSCI ozonesondes and $1.0 \% \mathrm{KI}$ solution result in higher amounts of ozone sensed. The results indicate that differences in solution composition and in ozonesonde type display little pressure dependence at pressures $\geq 30 \mathrm{hPa}$, and thus the transfer function can be characterized as a simple ratio of the less sensitive to the more sensitive method. This ratio is 0.96 for both solution concentration and ozonesonde type. The ratios differ at pressures $<30 \mathrm{hPa}$ such that $\mathrm{OZ}_{0.5 \%} / \mathrm{OZ}_{1.0} \%=0.90+0.041 \cdot \log _{10}(p)$ and $\mathrm{OZ}_{\text {SciencePump }} / \mathrm{OZ}_{\mathrm{ENSCI}}=0.764+0.133 \cdot \log _{10}(p)$ for $p$ in units of $\mathrm{hPa}$. For the manufacturer-recommended solution concentrations the dispersion of the ratio (SP-1.0/EN$0.5 \%$ ), while significant, is generally within $3 \%$ and centered near 1.0, such that no changes are recommended. For stations which have used multiple ozonesonde types with solution concentrations different from the WMO's and manufacturer's recommendations, this work suggests that a reasonably homogeneous data set can be created if the quanti- 
tative relationships specified above are applied to the nonstandard measurements. This result is illustrated here in an application to the Nairobi data set.

\section{Introduction}

Ozone is one of the critical atmospheric trace gases. Ozone contributes to the oxidizing capacity of the troposphere, to the absorption of terrestrial IR radiation, and to the absorption of solar UV in the stratosphere. An overabundance of ozone in the troposphere causes air quality problems, while a deficit in the stratosphere leads to enhanced exposure to UV. Ozone measurements are thus required to maintain our understanding of these processes, and they are required over times scales of hours to years and from single point measurements to vertical profiles to the mid-stratosphere. Measurements are required over hours at single locations to characterize air quality, while regular profiles over decades are required to characterize stratospheric ozone loss and to contribute to climate modeling.

Historically, the first ozone profile information was extracted from the Dobson measurements with the discovery of the Umkehr effect in the 1930s (Götz et al., 1934). In optimal (blue sky) conditions at sunrise and at sunset two coarse-resolution $(\delta z \approx 7 \mathrm{~km})$ vertical ozone profiles from about 15 to $50 \mathrm{~km}$ could be retrieved by this technique and the first stratospheric ozone climatology created (Dobson et al., 1927). Since this manual measurement method was demanding in personal resources, it is only since the mid-1950s that continuous Umkehr measurements have been available, and the technique continues to be improved (Fioletov et al., 2006; Petropavlovskikh et al., 2005). In the 1960s, wetchemical ozonesondes were developed, providing in situ, high-vertical-resolution ( $\delta z \approx 0.3 \mathrm{~km}$ or less) ozone profiles from the ground to the mid-stratosphere (Brewer and Milford, 1960; Komhyr, 1965). Data sets more than 30 years long are available based on this technique (Harris et al., 1998; Stähelin et al., 2001; Jeannet et al., 2007). In the 1970s, the satellite epoch began providing global coverage of the total ozone column (e.g., Labow et al., 2013). In the 1990s, the active lidar and the passive microwave were developed with an improved time resolution and an extended altitude range up to the mesosphere (Beekman et al., 1994; Calisesi et al., 2003; Moreira et al., 2015). Today, the full suite of ground-based, balloon-borne, and satellite instruments provides significant spatiotemporal coverage of global ozone. Maintaining this coverage requires all three platforms. Satellite instruments have limited lifetimes and require comparison measurements with other instruments for algorithm development and reference measurements. Balloon-borne instruments provide the highest vertical resolution and the highest sensitivity but are limited in spatial and temporal coverage. Ground-based instruments are required for long time series with single reference instruments and for daily measurement capability (e.g., Guirlet et al., 2000). Modeling activities ranging from weather forecasts to climate studies benefit from ozone distribution measurements from all three platforms (Stein et al., 2000; Cionni et al., 2011).

Ozone is recognized as an essential climate variable (ECV), and target observation requirements for satellitebased products for climate are defined by the Global Climate Observing System (GCOS), which is a joint undertaking of the World Meteorological Organization (WMO), the United Nations Environmental Programme, and others (GCOS, 2010). The measurement requirements for an ECV represent a challenge even for ground-based instruments:

1. accuracy: $10 \%$ (troposphere), $5 \%$ (stratosphere);

2. spatial resolution: Horizontal: $5-50 \mathrm{~km}$ (troposphere), 50-100 km (stratosphere);

3. vertical resolution: $0.5 \mathrm{~km}$ (troposphere), $0.5-3 \mathrm{~km}$ (stratosphere);

4. 3-hourly observing cycle everywhere;

5. stability: $1 \%$ (troposphere), $0.6 \%$ (stratosphere).

\subsection{Contributions of electrochemical concentration cell ozonesonde measurements}

Since the late 1960s the vast majority of vertical ozone profile information has been from individual ozonesonde flights. The instruments used are all based on measurements of an electrical current from an electrochemical galvanic cell, which is a measure of the amount of ozone sampled. The current is generated when ozone in the air, which is bubbled through an electrolytic solution, reacts with iodide ions in the electrolyte in the cell. Variations of this principle, described in detail in Sect. 2.1, led to the Brewer-Mast (BM) ozonesonde (Brewer and Milford, 1960), the Japanese KC ozonesonde (Komhyr and Harris, 1965; Kobayashi and Toyama, 1966), and the electrochemical concentration cell (ECC) ozonesonde (Komhyr, 1969). The BM ozonesonde consists of a single electrochemical cell with a potential applied across the silver anode and platinum cathode immersed in an alkaline potassium iodide (KI) solution. The $\mathrm{KC}$ ozonesonde has a platinum cathode and carbon anode immersed in a pH-neutral KI solution. The ECC ozonesonde consists of two half cells, each containing a platinum electrode, and differing concentrations of iodide $\mathrm{I}^{-}$in the form of KI, saturated at the anode and dilute at the cathode. From these three electrochemical cell possibilities, the ECC ozonesonde has emerged as the preferred technology. One station continues using the BM ozonesonde for data continuity. The $\mathrm{KC}$ ozonesonde is no longer in use. Here we focus on the ECC ozonesonde.

While the ECC was under development, different concentrations of $\mathrm{KI}$ in the cathode were investigated, and the results 
compared with corresponding total column measurements. In the 1980 s solution concentrations of 1.5 and $1.0 \%$ were in use (Barnes et al., 1985; Komhyr et al., 1995a). By the mid1980s a $1.0 \%$ solution of KI became the standard recommendation for Science Pump (SP) ozonesondes (Komhyr, 1986). SP was the only manufacturer of ECC ozonesondes until the mid-1990s, when the company ENSCI (EN) was formed, which began manufacturing an alternate ECC ozonesonde. Initially ENSCI also recommended a KI concentration of $1.0 \%$ for the cathode; however, this was changed to $0.5 \%$ after unpublished comparisons of EN and SP ozonesondes using $1.0 \% \mathrm{KI}$ indicated that EN ozonesondes recorded more ozone than the SP ozonesondes at the same solution concentration.

These changes created some confusion as recommendations in the preparation of ECC ozonesondes changed. The first results comparing ozonesondes flown with 1.0 and $0.5 \%$ KI cathode solution were based on only a few comparisons (Boyd et al., 1998). More extensive results were obtained from comprehensive intercomparisons in the laboratory (Smit et al., 2007) and in the field (Kivi et al. 2007; Deshler et al., 2008). These comparisons led to the current WMO recommendations for ECC ozonesonde preparations (Smit and ASOPOS Panel, 2014); however, between the mid1990s and late 2000s the ozonesonde community was using several combinations between 1.0 and $0.5 \% \mathrm{KI}$ cathode cell concentrations in SP and EN ozonesondes. In some cases, other concentrations were also used, such as $2.0 \%$, but we focus here on the manufacturer-recommended concentrations of 1.0 and $0.5 \%$.

\subsection{Need for homogenization of ECC ozonesonde measurements}

The Montreal Protocol, signed in 1991, established the publication every 4 years of an ozone assessment (e.g., WMO, 2010, 2014). One of the most comprehensive reports regarding measurement techniques was the SPARC/IOC/GAW (Stratospheric Processes And their Role in Climate/International Ozone Commission/Global Atmospheric Watch) study (WMO, 1998). An update of this study, the SI2N (SPARC/IGACO (Integrated Global Atmospheric Chemistry Observations)/IOC/NDACC (Network for the Detection of Atmospheric Composition Change)) initiativeto report the present state of knowledge of the different techniques and to reprocess long time series accordingly, is being covered in a special issue of Atmos. Chem. Phys., Atmos. Meas. Tech., and ESSD. A parallel European Space AgencyCCI (Climate Change Initiative) project was established in 2011 to improve the satellites' products for the prominent ECVs, one being ozone. Comparisons with current satellite measurements of ozone, and future instrumental improvements for new satellite generations, require more accurate ground-based data series for validation (Liu et al., 2006; Hubert et al., 2016). Such comparisons have a rich heritage in previous field campaigns comparing various methods to measure ozone (Hilsenrath et al., 1986; Kerr et al., 1994; Margitan et al., 1995; Komhyr et al., 1995b; Meijer et al., 2004).

The MOZAIC data sets (e.g., Thouret et al., 1998, 2006), obtained from in-service aircraft provide a comparison to tropospheric ozonesonde measurements especially at the tropopause, where ozone profiles are at their minimum values. Staufer et al. $(2013,2014)$ found a systematic difference with ozonesondes when aircraft measurements were compared to ozonesonde measurements determined by matching balloon and aircraft measurements via air parcel trajectory calculations, concluding an overestimation by the ozonesondes on the order of 5-10\% in the upper-troposphere-lowerstratosphere region. Logan et al. (2012) extensively analyzed tropospheric ozonesonde data by comparison to MOZAIC aircrafts' ascent/descent profiles and to high-altitude groundbased measurements, pointing out biased and suspicious data sets.

Clear improvement of ozonesonde measurement precision for properly prepared and analyzed instruments is shown in recent comparison experiments for both the EN and SP instruments (Smit et al., 2007; Deshler et al., 2008; Thompson et al., 2012). A good sign of the stability of these results in the last 10 years has been confirmed in recent studies, e.g., Logan et al. (2012). These results are not the case for the accuracy of measurements with "provider-solution" combinations which differ from the recommendations. Such combinations typically deviate from trusted ozone measurements by $5-10 \%$. These latter deviations are now reasonably well characterized by a large set of comparison measurements (Table 1). Thus, it is time to apply corrections to ozonesonde data measured with provider-solution combinations differing from the standard WMO recommendations. Such applications will homogenize these data sets and thereby improve data quality, usefulness for trend analysis, global homogeneity, and references for satellites and models. The appropriate corrections to apply, using the large comparison data set available, are developed in Sects. 3 and 4.

To homogenize these records to a single standard requires transfer functions to convert measurements made with any of the various combinations to one of the two WMO recommended standard preparations: 1.0 for SP and $0.5 \%$ for $\mathrm{EN}$ for the KI concentrations of the cathode electrolyte. Obtaining these transfer functions is the goal of this paper.

The transfer functions will be derived from published and unpublished measurements which compare directly the response of SP and EN ECC ozonesondes using 1.0 and $0.5 \%$ concentrations of $\mathrm{KI}$ in the cathode cells under identical environments of ozone, pressure, and temperature. These comparisons were done in an environmental simulation chamber in Jülich, Germany (Smit et al., 2007), Jülich Ozone Sonde Intercomparison Experiment 2009, henceforth JOSIE09; on a multiple-ECC-ozonesonde gondola (Deshler et al., 2008), Balloon Experiment on Standards for OzoneSondes, henceforth the BESOS experiment; on other multiple-ozonesonde 
Table 1. Data sets used in the analysis giving experiment or location, years of the comparisons, location latitude and longitude, ozonesonde and solution strengths compared, number of comparisons, sampling frequency of the data (Hz), and the platform. The multi-sonde platforms contained from 4 to 12 ozonesondes.

\begin{tabular}{|c|c|c|c|c|c|c|c|c|}
\hline Location & Dates & Lat. & Long. & \multicolumn{2}{|c|}{$\begin{array}{l}\text { Provider concen. } \\
\text { compared }\end{array}$} & No. & $\begin{array}{r}\text { Freq. } \\
(\mathrm{Hz})\end{array}$ & $\begin{array}{l}\text { Platform/ } \\
\text { gondola }\end{array}$ \\
\hline JOSIE09 & 1996-2000 & 50.9 & -6.4 & $\begin{array}{l}\text { EN-0.5 } \\
\text { SP-0.5 } \\
\text { SP-1.0 } \\
\text { SP-0.5 } \\
\text { SP-1.0 }\end{array}$ & $\begin{array}{l}\text { EN-1.0 } \\
\text { SP-1.0 } \\
\text { EN-1.0 } \\
\text { EN-0.5 } \\
\text { EN-0.5 }\end{array}$ & $\begin{array}{l}3 \\
3 \\
7 \\
5 \\
3\end{array}$ & 1 & Simulator \\
\hline BESOS & April 2004 & 41.3 & 105.7 & $\begin{array}{l}\text { EN-0.5 } \\
\text { SP-0.5 } \\
\text { SP-1.0 } \\
\text { SP-0.5 } \\
\text { SP-1.0 }\end{array}$ & $\begin{array}{l}\text { EN-1.0 } \\
\text { SP-1.0 } \\
\text { EN-1.0 } \\
\text { EN-0.5 } \\
\text { EN-0.5 }\end{array}$ & $\begin{array}{l}9 \\
9 \\
9 \\
9 \\
9\end{array}$ & 0.5 & Multi-sonde \\
\hline Payerne & $\begin{array}{l}2002-2003 \\
2005-2006\end{array}$ & 46.8 & -6.9 & $\begin{array}{l}\text { En-0.5 } \\
\text { SP-1.0 }\end{array}$ & $\begin{array}{l}\text { EN-1.0 } \\
\text { EN-0.5 }\end{array}$ & $\begin{array}{l}48 \\
26\end{array}$ & 0.15 & $\begin{array}{l}\text { Dual-sonde } \\
\text { Dual-sonde }\end{array}$ \\
\hline McMurdo & 1996-2006 & -77.8 & 166.7 & EN-0.5 & EN-1.0 & 18 & 0.15 & Dual-sonde \\
\hline Sodankylä & 1995-2002 & 67.4 & -26.6 & $\begin{array}{l}\text { EN-0.5 } \\
\text { SP-1.0 } \\
\text { SP-1.0 }\end{array}$ & $\begin{array}{l}\text { EN-1.0 } \\
\text { EN-1.0 } \\
\text { EN-0.5 }\end{array}$ & $\begin{array}{l}4 \\
8 \\
5\end{array}$ & 1 & $\begin{array}{l}\text { Multi-/dual- } \\
\text { sonde }\end{array}$ \\
\hline Wallops I. & 1995-2002 & 37.8 & 75.5 & SP-0.5 & SP-1.0 & 16 & 1 & Dual-sonde \\
\hline Laramie & 1996 & 41.1 & 105.6 & EN-0.5 & EN-1.0 & 6 & 1 & Multi-sonde \\
\hline Total & & & & $\begin{array}{l}\text { EN-0.5 } \\
\text { SP-0.5 } \\
\text { SP-1.0 } \\
\text { SP-0.5 } \\
\text { SP-1.0 }\end{array}$ & $\begin{array}{l}\text { EN-1.0 } \\
\text { SP-1.0 } \\
\text { EN-1.0 } \\
\text { EN-0.5 } \\
\text { EN-0.5 }\end{array}$ & $\begin{array}{l}88 \\
28 \\
24 \\
14 \\
43\end{array}$ & & $\begin{array}{l}\text { KI conc. diff. } \\
\text { KI conc. diff. } \\
\text { Sonde diff. } \\
\text { Sonde diff. } \\
\text { Recommended }\end{array}$ \\
\hline
\end{tabular}

balloon flights (Kivi et al., 2007); and on unpublished dualozonesonde flights from Payerne, Switzerland; McMurdo Station, Antarctica; Sodankylä, Finland; Wallops Island, Virginia, USA; and Laramie, Wyoming, USA. Together 197 comparisons of the different possible combinations have been made at these sites with the goal of developing transfer functions to convert measurements made with either manufacturer and with either 1.0 or $0.5 \% \mathrm{KI}$ concentration to one of the WMO recommendations: SP with $1.0 \% \mathrm{KI}$, EN with $0.5 \% \mathrm{KI}$.

The basic ECC principles, operation, and uncertainties are described in the next section. Section 3 describes the database and the methods to establish the transfer functions. Section 4 describes the methods and the results for the derivation of the transfer functions. The results are discussed in Sect. 5, and then conclusions appear in Sect. 6.

\section{ECC ozonesonde description}

\subsection{ECC ozonesonde principles}

Ozonesondes are based on an electrochemical cell where the chemical potential difference is maintained by differences in the iodide $\left(\mathrm{I}^{-}\right)$concentration in each half cell. Ozone introduced into the dilute iodide half cell, containing the cathode, reacts with iodide and converts it to iodine $\left(\mathrm{I}_{2}\right)$ in the following reaction (Komhyr, 1969):

$\mathrm{KI}+\mathrm{O}_{3}+\mathrm{H}_{2} \mathrm{O} \rightarrow 2 \mathrm{KOH}+\mathrm{I}_{2}+\mathrm{O}_{2}$,

followed at the cathode by the reduction of iodine back to potassium iodide:

$\mathrm{I}_{2}+2 e \rightarrow 2 \mathrm{I}^{-}$.

The two electrons arise from the electrolyte saturated in iodide at the anode in the other half cell by the oxidation of iodide:

$3 \mathrm{I}^{-} \rightarrow \mathrm{I}_{3}^{-}+2 e$. 


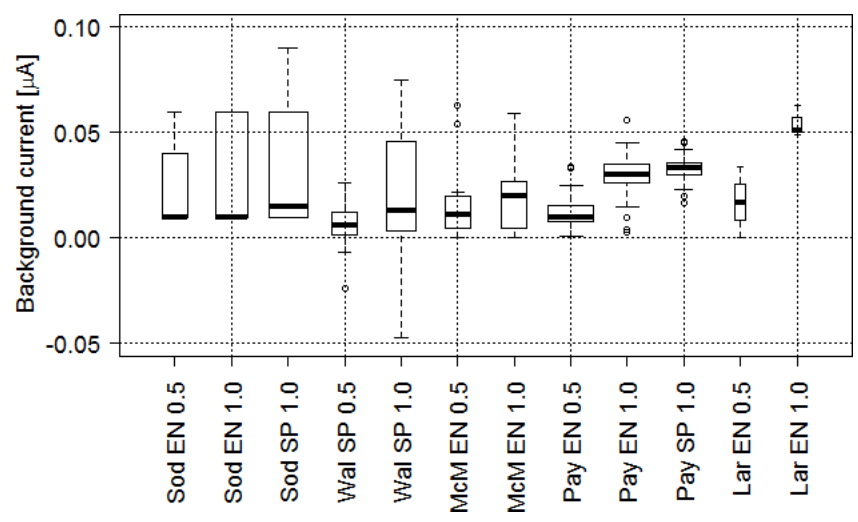

Figure 1. Boxplot of the background current $(\mu \mathrm{A})$ measured at the five stations which flew a number of dual- or multi-ozonesonde gondolas: Sodankylä (Sod), Wallops Island (WaI), McMurdo Station $(\mathrm{McM})$, Payerne (Pay), and Laramie (Lar). Following the station location, the ozonesonde manufacturer (EN or SP) and then the KI solution concentration $(0.5$ or $1.0 \%)$ are identified. Medians are the thick black segments, the interquartile range is the box height, 1.5 times the interquantile range are the whiskers, outliers are denoted as circles, and the square root of the number of measurements is reflected in the box width. A value of $0.03 \mu \mathrm{A}$ corresponds to $0.1 \mathrm{mPa}$ of ozone.

The outer electrical circuit consists of two platinum electrodes immersed in the half-cell electrolytes which are aqueous solutions of KI. The electrolyte is saturated with KI on the anode side and with a dilute KI concentration on the cathode side. Besides KI, the electrolytes also contain potassium bromine and sodium phosphate buffers to maintain a neutral $\mathrm{pH}$ solution. The decomposition of each ozone molecule in the dilute electrolyte produces a transfer of electrons (Eq. 2) in the outer circuit following Faraday's law of electrolysis. Converting the mass of ozone decomposed to partial pressure with the ideal gas law and substituting $e \cdot N_{\mathrm{A}}$ for Faraday's constant results in the following relationship between ozone partial pressure and electrical current:

$\mathrm{O}_{3}(p)=\frac{R}{\left(z \cdot e \cdot N_{\mathrm{A}}\right)} \cdot \frac{\varphi(p)}{P_{\mathrm{E}}(p)} \cdot \frac{T_{P}(p)}{\mathrm{FR}} \cdot\left(i(p)-i_{0}\right)$.

$R$ is the universal gas constant; $z$ the number of electrons required to convert the iodine in the dilute electrolyte back to iodide; $e$ the elementary charge; $N_{\mathrm{A}}$ Avogadro's number; $i(p)$ the measured cell current as a function of atmospheric pressure, $p ; i_{0}$ the background current; $\varphi(p)$ the effective stoichiometry factor of the chemical conversion of ozone into iodine; $T_{\mathrm{p}}(p)$ the pump temperature, a surrogate for the temperature of the air sampled; FR the flow rate; and $P_{\mathrm{E}}(p)$ the pump efficiency correction to account for decreasing flow rate at low pressures. Operationally, for $i(p)$ in units of $\mu \mathrm{A}$, $z=2$, and FR in units of $\mathrm{mL} \mathrm{s}^{-1}$, the leading term in Eq. (4), $R /\left(z e N_{\mathrm{A}}\right)$, is replaced by $4.3085 \times 10^{-6}$, which gives ozone partial pressure in units of $\mathrm{mPa}$.

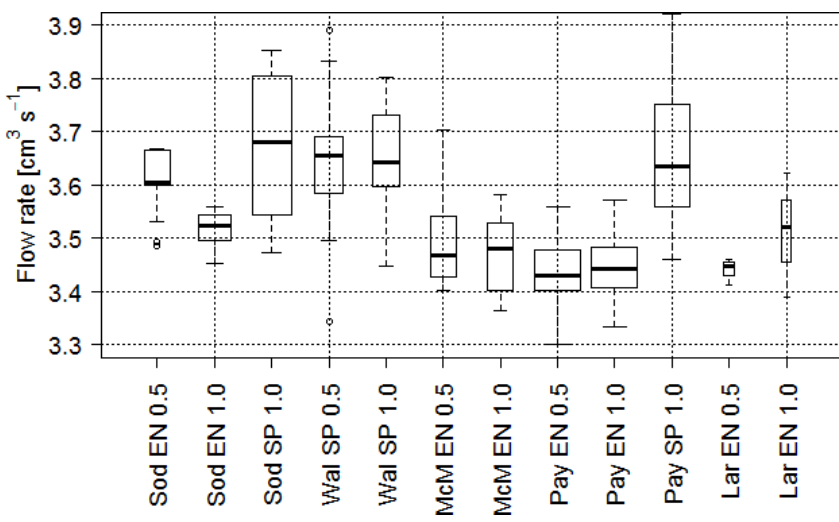

Figure 2. Ozonesonde pump flow rates $\left(\mathrm{cm}^{3} \mathrm{~s}^{-1}\right)$ measured at the different stations, following the nomenclature of Fig. 1 for the station and ozonesonde.

Each of the terms in Eq. (4) has an uncertainty deduced from the measurement method, but they also have an additional uncertainty which is more difficult to quantify, especially at high altitude (low pressure) levels. The background current, flow rate, pump temperature, and stoichiometry of ozone to iodine require special mention.

The background current $i_{0}$ is a measure of the residual signal with "zero air" (no ozone) at the ozonesonde inlet. Originally, $i_{0}$ was attributed to side chemical reactions with oxygen and, therefore, expected to decrease with altitude; however, Thornton and Niazy $(1982,1983)$ and other empirical evidence from laboratory tests suggested that $i_{0}$ is constant independent of altitude. Figure 1 gives the range of $i_{0}$ measured at the different stations prior to the measurement flights considered in this analysis. A mid-value of $0.03 \mu \mathrm{A}$ from Fig. 1 corresponds to $0.1 \mathrm{mPa}$ and produces an offset of the ozone profile and a diminution of the ozone column by 5.4 DU, $0.1 \mathrm{mPa}$ integrated from 1000 to $1 \mathrm{hPa}$, or $1.8 \%$ for a $300 \mathrm{DU}$ ozone column. These $i_{0}$ values will be discussed again in Sect. 3.2, but the value of $i_{0}$ does not affect comparisons between cells with similar backgrounds and is thus less important for the work here.

The flow rate is well characterized in the laboratory preparation at surface pressure as shown in the box-and-whisker plot of the flow rates (Fig. 2) measured at the different stations. The median values for each ozonesonde type are within $0.3 \mathrm{~mL} \mathrm{~s}^{-1},<10 \%$, showing the good concordance between stations, although there is a $0.2 \mathrm{~mL} \mathrm{~s}^{-1}$ systematic difference between the majority of SP and EN ozonesondes. The real flow rate is much less certain under low-pressure (highaltitude) conditions, where the pump efficiency decreases and pressure against the flow from the height of the solution in the ECC cell, on the order of $1-2 \mathrm{hPa}$, becomes non-negligible. Thus a pump efficiency correction is applied through the factor $P_{\mathrm{E}}(p)$; however, there is still disagreement on the correct $\mathrm{PE}(p)$ to use (Johnson et al., 2002). The pumps are designed for a constant rotation speed during a flight, a 
characteristic which has been checked by several investigators here but not published.

The effective stoichiometric factor, $\varphi(p)$ as formulated in Eq. (4), is composed of two factors: the absorption of ozone in the electrolytic solution, and the stoichiometric efficiency of the reaction of $\mathrm{O}_{3}$ and $\mathrm{KI}$ to produce $\mathrm{I}_{2}$. This latter factor is more difficult to characterize. In theory it is close to 1 . The absorption efficiency has been measured in the laboratory with two ECC ozonesondes measuring in series. These tests have shown that the absorption of ozone is somewhat dependent on the amount of solution used (e.g., $2.5 \mathrm{~mL}$ vs. $3.0 \mathrm{~mL}$; Tarasick et al., 2016; Davies et al., 2003), with the absorption increasing from 0.96 as the amount of solution increases from $2.5 \mathrm{~mL}$. The increase of the gas diffusion rate during balloon ascent due to the pressure decrease should limit this ozone conversion efficiency loss to the lower part of the profile (Davies et al., 2003).

All these factors are eventually time and pressure dependent, and they superpose each other, which makes their individual contribution particularly difficult to determine. The factors which are of particular concern for the issue of varying ozonesonde manufacturer and cathode solution concentration are contained in the terms $z$ and $\varphi(p)$.

The details of the differences in ozonesonde manufacturer and how they affect these terms can only be speculated on at this time. The SP and EN ozonesondes are in principle the same, yet the EN ozonesondes consistently indicate a higher ozone amount when compared to an SP ozonesonde with the same sensor KI electrolyte concentration. The differences in cell manufacturer may affect the efficiency of electron release at the anode and electron gain by iodine at the cathode, which could be related to differences in the platinum electrode sensitivity and the ion bridge conductance. The inner surface proprieties of the cell walls are different and may affect reactions of ozone and the cell walls. Either of these would affect $z$.

Differences in KI concentration in the dilute electrolytic solution likely affects the efficiency of the conversion of $\mathrm{O}_{3}$ into $\mathrm{I}_{2}$ through reaction with $\mathrm{KI}$, thus affecting $\varphi(p)$. As will be shown, the effect of differences in KI concentration is very similar to the effect of different ozonesonde type. A detailed study of the reasons for the differences between ozonesonde type and KI concentrations has not been performed and is beyond the scope of this paper.

\subsection{Review of the standard WMO recommendations}

The preparation before the flight of an ECC ozonesonde is crucial for its performance. The standard operating procedures (SOPs) for ECC ozonesondes have been established by a group of experts under the guidance of the World Calibration Center for Ozonesondes (WCCOS) of the WMO (Smit and the ASOPOS panel, 2014). These results are from a 10year coordinated process to improve the different aspects of ECC ozonesonde preparation and data processing. Operat- ing the ECC ozonesondes under these prescribed rules has been tested extensively in different JOSIE experiments at the Jülich Research Center (Smit et al., 2007). The large balloon experiment BESOS was designed as an extension in the real atmosphere of these laboratory developments (Deshler et al., 2008). In addition to 18 ozonesondes, the BESOS gondola included also the Jülich reference UV spectrometer (Proffitt and McLaughlin, 1983; Smit et al., 2007) to replicate as far as possible the test procedure of the JOSIE experiments. The two experiments agree on the following conclusions:

1. ECC ozonesondes prepared according to the SOPs provide very reproducible $(<2-3 \%)$ measurements.

2. The results depend on the ozonesonde manufacturer (e.g., EN vs. SP) and on the sensing solution concentration (e.g., $0.5 \%$ vs. $1.0 \%$ ). The order of magnitude of the differences is $5 \%$.

3. The combinations EN- $0.5 \%$ and $\mathrm{SP}-1.0 \%$ as providersolution agree with each other to within $2 \%$ but overestimate the reference UV photometer in the stratosphere by $5-10 \%$. However, the total ozone column estimated from these combinations on the BESOS gondola agreed with a collocated Dobson spectrophotometer.

4. It is possible to reconcile the measurements made with other provider-solution combinations and the photometer with the help of a simple linear in $\ln (p)$ transfer function.

JOSIE and BESOS were completed under conditions not reflecting directly the diversity of the operational services around the world. Each sounding station has specific instrumentation and operators even though they follow the same procedures. It is therefore important to verify that the conclusions from JOSIE and BESOS are also reflected in results of several operational stations. At the stations, it is not possible to fly a reference UV instrument so only relative differences can be derived from dual- or multiple-ozonesonde flights. In the present analysis the JOSIE and BESOS results will be analyzed in a similar way to the other dual- and multiinstrument flights.

\subsection{Review of previous solution concentration and provider comparisons}

In the mid-1990s the problems of differences in providersolution combinations were still of marginal importance (SPARC, 1998). The ENSCI company had entered the market only a few years earlier, and the disparate preparation procedures prevented clearly identifying problems. The conclusions at that time were that the effect of changes in ECC KI solution concentrations were complex and required further study before clear recommendations could be provided.

McPeters et al. (1999) report a $2 \%$ consistency from five triple ECC flights during a validation campaign at Mauna 
Loa in 1995 using EN-1.0\% ozonesondes. The authors report that the ozonesondes overestimate the Dobson measurements by an average of $5 \%$. In profile, above $25 \mathrm{~km}$, the ozonesonde measurements are greater than the lidar and microwave measurements by a similar amount. Boyd et al. (1998) presented ozone profile differences from EN ozonesondes with 1.0 and $0.5 \%$ KI solutions at Lauder, New Zealand. A 5-6\% systematic overestimation of ozone by the $1 \%$ solution compared to the $0.5 \%$ with the EN ozonesondes is evidenced by comparison of the ozone profile and total column collocated lidar and Dobson measurements.

For an analysis of the transition from Brewer-Mast to ECC (EN-1.0\%) ozonesondes, the ECC data were normalized to the Dobson column to be consistent with the Brewer-Mast SOPs (Stübi et al., 2008). Stübi et al. found that the ECC ozonesondes systematically overestimated the total ozone column with a mean normalization factor of 0.95 for more than 100 dual-ozonesonde flights between ECC and BM, indicating an overestimation of $5 \%$ of the ozone column by EN-1.0\% ozonesondes.

Kivi et al. (2007) analyzed a series of dual- and multipleozonesonde flights with SP and EN instruments using 0.5 and $1.0 \%$ sensing solutions. For the homogenization of ozone profiles from the northern high-latitude stations the authors derived a third-order polynomial correction based on altitude to correct the overestimation of ozone from EN-1.0\% compared to SP-1.0\%.

The laboratory work (Smit et al., 2007) and the several field measurements (Boyd et al., 1998; McPeters et al., 1999; Stübi et al., 2008; Kivi et al., 2007; Deshler et al., 2008) all indicate a relatively consistent systematic bias, on the order of $5 \%$, between the different ozonesonde manufacturers with the same electrolytic concentration and between different electrolyte concentrations in ozonesondes from a single manufacturer.

\subsection{Chemistry of the ECC ozonesonde}

The early stoichiometric work on the yield of iodine from ozone showed varying results, with much of the uncertainty arising from the variety of KI sensing solutions, $\mathrm{pH}$ buffers, and sensors used (Saltzman and Gilbert, 1959; Boyd et al., 1970; Dietz et al., 1973; Pitts et al., 1976; Lanting, 1979). Common to many of the references was the suggestion of a secondary reaction producing additional iodine perhaps from reactions of iodide with the phosphate buffers. Johnson et al. (2002) showed that the same type of ECC ozonesonde operated with differing amounts of $\mathrm{KI}$, and corresponding changes in the phosphate buffers, provides slightly different stoichiometric ratios of iodine to ozone. In fact these differences were very apparent in the initial development of the ECC ozonesondes (Komhyr, 1969, 1986).

\section{Methods to establish the transfer functions}

\subsection{Summary of data sets considered in the present analysis}

The present analysis of dual-ozonesonde measurements is an extension of the JOSIE and BESOS experiments to link short-term instrument comparison campaigns to routine operations at regular sounding stations. The JOSIE experiments were conducted in a controlled atmospheric chamber. BESOS and the other comparisons were conducted via balloon flights under real atmospheric conditions. JOSIE and BESOS used the same reference UV photometer (Proffitt et al., 1983) for the final comparisons, and the results of those comparisons confirmed the high precisions and good accuracy of well-prepared ozonesondes. For the extensive additional data presented here an independent (e.g., photometric) reference is not available; rather the ozonesondes are compared pairwise. The JOSIE and BESOS data are included here also pairwise (Table 2). The first of these dual-ozonesonde comparisons began in the late 1990s at different locations. Although there was no coordinated effort, the motivation at each station was similar: the need for homogenization of the long-term ozonesonde record at the station. Table 1 summarizes the data sets used for the present analysis. Differences in the details of these comparisons at the different stations are described below.

While the differences are described below, the comparisons were the same in following the SOPs established by Smit and the ASOPOS panel (2014) in the preparation of each ozonesonde and in using only $0.5 \%$ or $1.0 \% \mathrm{KI}$ buffered cathode solutions. The $0.5 \% \mathrm{KI}$ cathode solutions were created by diluting the standard buffered $1.0 \% \mathrm{KI}$ solution by $50 \%$ with distilled deionized water. The standard $1.0 \% \mathrm{KI}$ solution is created by dissolving the following in distilled deionized water: $10 \mathrm{~g} \mathrm{KI}, 25 \mathrm{~g} \mathrm{KBr}, 1.25 \mathrm{~g}$ $\mathrm{NaH}_{2} \mathrm{PO}_{4} \mathrm{H}_{2} \mathrm{O}$, and $5 \mathrm{~g} \mathrm{Na}_{2} \mathrm{HPO}_{4} \cdot 12 \mathrm{H}_{2} \mathrm{O}$, and then adding enough distilled water to make $1 \mathrm{~L}$ of solution.

\subsubsection{JOSIE09 - ozone profile simulation chamber, Jülich, Germany}

The JOSIE experiments have been described by Smit and Kley (1998), Smit and Sträter (2004a, b), and Smit et al. (2007), so only the experimental principles are reviewed here. Four ozonesondes can be placed simultaneously in the atmospheric simulator. Pressure and temperature can be regulated from surface conditions to $10 \mathrm{hPa}$ and $-70^{\circ} \mathrm{C}$. The ozone flow is controlled in a glass cavity and measured in parallel by the ozonesondes and a reference UV photometer. Different types of "temperature-pressure-ozone" profiles are generated to simulate high-, middle-, or tropical-latitude profiles. In the present analysis, only pairs of ozonesondes, representing different provider-solution combinations, simultaneously operated in the chamber are considered. This ex- 
Table 2. Mean and standard deviations of the various comparison measurements. The mean ratio is equivalent to the slope of a linear fit to the data which passes through the origin. For the data sets with the most data and the most varied comparisons the means and standard deviations are given for the pressure intervals indicated at the top. For the other data sets the means and standard deviations are given for all the data without regard to pressure.

\begin{tabular}{|c|c|c|c|c|c|c|c|c|}
\hline Source & Sonde/KI & From & To & $999>p>500$ & $500>p>100$ & $100>p>30$ & $30>p$ & Box \\
\hline JOSIE09 & EN & $1.0 \%$ & $0.5 \%$ & $0.96 \pm 0.02$ & $0.95 \pm 0.04$ & $0.94 \pm 0.05$ & $0.91 \pm 0.07$ & 1 \\
\hline BESOS & EN & & & $0.95 \pm 0.07$ & $0.95 \pm 0.03$ & $0.95 \pm 0.04$ & $0.94 \pm 0.01$ & \\
\hline Payerne & EN & & & $0.97 \pm 0.84$ & $0.97 \pm 0.05$ & $0.96 \pm 0.03$ & $0.94 \pm 0.04$ & \\
\hline McMurdo & EN & & & $0.97 \pm 0.04$ & $0.96 \pm 0.06$ & $0.96 \pm 0.09$ & $0.92 \pm 0.06$ & \\
\hline Sodankylä & EN & & & $0.93 \pm 0.03$ & All data & & & \\
\hline Wallops I. & EN & & & $0.92 \pm 0.06$ & All data & & & \\
\hline Laramie & EN & & & $0.96 \pm 0.04$ & All data & & & \\
\hline JOSIE09 & SP & $1.0 \%$ & $0.5 \%$ & $0.97 \pm 0.02$ & $0.97 \pm 0.02$ & $0.98 \pm 0.03$ & $0.93 \pm 0.06$ & 2 \\
\hline BESOS & SP & & & $0.97 \pm 0.02$ & $0.96 \pm 0.02$ & $0.95 \pm 0.02$ & $0.93 \pm 0.02$ & \\
\hline Wallops I. & SP & & & $0.94 \pm 0.06$ & All data & & & \\
\hline JOSIE09 & $1.0 \%$ & SP & EN & $0.96 \pm 0.02$ & $0.94 \pm 0.05$ & $0.94 \pm 0.12$ & $0.93 \pm 0.05$ & 3 \\
\hline BESOS & $1.0 \%$ & & & $0.97 \pm 0.13$ & $0.97 \pm 0.03$ & $0.96 \pm 0.04$ & $0.96 \pm 0.02$ & \\
\hline Sodankylä & $1.0 \%$ & & & $0.95 \pm 0.03$ & All data & & & \\
\hline JOSIE09 & $0.5 \%$ & SP & EN & $0.96 \pm 0.03$ & $0.95 \pm 0.04$ & $0.96 \pm 0.06$ & $0.94 \pm 0.05$ & 4 \\
\hline BESOS & $0.5 \%$ & & & $1.00 \pm 0.07$ & $0.98 \pm 0.03$ & $0.96 \pm 0.03$ & $0.96 \pm 0.02$ & \\
\hline JOSIE09 & & SP-1.0 & EN-0.5 & $1.01 \pm 0.04$ & $0.99 \pm 0.03$ & $1.00 \pm 0.04$ & $0.98 \pm 0.03$ & 5 \\
\hline BESOS & & & & $1.02 \pm 0.13$ & $1.03 \pm 0.03$ & $1.01 \pm 0.03$ & $1.02 \pm 0.02$ & \\
\hline Payerne & & & & $1.03 \pm 0.46$ & $1.00 \pm 0.06$ & $1.00 \pm 0.04$ & $1.01 \pm 0.03$ & \\
\hline Sodankylä & & & & $1.02 \pm 0.03$ & All data & & & \\
\hline
\end{tabular}

plains the low number of comparisons available for these data.

\subsubsection{BESOS - balloon-borne multi-instrument gondola, Laramie, Wyoming}

The BESOS experiment was described fully by Deshler et al. (2008). A collaborative team of ozonesonde experts prepared a balloon gondola $(100 \mathrm{~kg})$ with 16 ozonesondes, the Jülich UV photometer (Proffitt et al., 1983), a Vaisala radiosonde, and a data acquisition system. Dobson and Brewer spectrophotometers were available at the launch site. The flight to $32 \mathrm{~km}$ was completed on 13 April 2004 from Laramie, Wyoming. The data from this flight are used here similarly to the JOSIE data by considering the ozonesondes pairwise. The payload had a set of 12 standard ozonesondes, six from EN and six from SP; out of each set of six ozonesondes, three had a $0.5 \%$ and three a $1.0 \% \mathrm{KI}$ solution concentration. Thus, a set of nine pairs is available for comparison for each provider-solution combination (Table 1). The correlation matrix for any one of the three pairs of a comparison indicated little variation in the correlation coefficient for any combination of the two types of ozonesondes being compared. This suggests that covariance does not negate the independence of the nine comparisons for any combination of ozonesonde type or solution concentration.

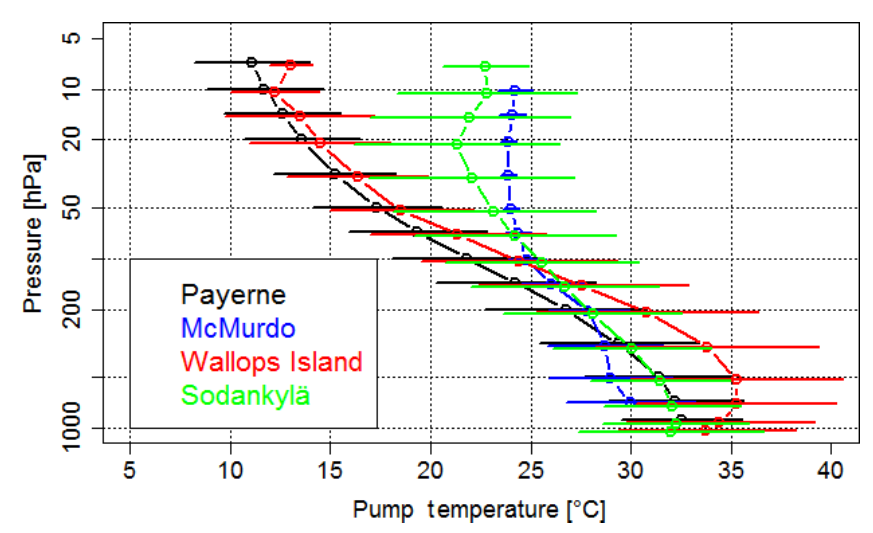

Figure 3. Mean profile of the measured pump temperature for the different dual-ozonesonde flight data sets. The higher pump temperature at the upper part of the profiles for the McMurdo and Sodankylä stations is due to a heat source to avoid freezing of the solution. Error bars are 1 standard deviation of the measurements.

\subsubsection{Payerne, Switzerland - balloon-borne dual-ozonesonde gondolas}

The Payerne station is run under the responsibility of MeteoSwiss, and the radiosondes used were the SRS model from the Swiss company Meteolabor. SRS radiosondes are not capable of interfacing two ozonesondes, so for the dual- 
ozonesonde flights two independent receiving systems were used. These were synchronized at the time of the launch to better than $1 \mathrm{~s}$, and the sampling frequency was about $7 \mathrm{~s}$. For the analysis, the data are interpolated to a common timescale to avoid any problems related to a difference of the pressure readings from the two ozonesondes. The data sets consist of two campaigns embedded in the operational service as a dual-ozonesonde flight for the Wednesday sounding, with the reference (operational) ozonesonde being the EN-0.5\%. The data sets consist of

1. 48 pairs of EN-0.5\% and EN-1.0\% during June 2002July 2003,

2. 26 pairs of EN-0.5\% and SP-1.0\% during May 2005December 2006.

\subsubsection{McMurdo Station, Antarctica - balloon-borne dual-ozonesonde gondolas}

Measurements from McMurdo Station, Antarctica, were conducted by the University of Wyoming during the ozone hole period, August-November 1986-2010 (Mercer et al., 2007). From this record 18 flights with two EN ozonesondes interfaced to a single microprocessor and Vaisala RS80 radiosonde were completed. The years (number of flights) are 1996 (3), 1999 (1), 2000 (1), 2002 (6), and 2006 (7). In each case EN-1.0\% and EN-0.5\% KI concentration solutions were compared. The low-temperature conditions in Antarctica require a heater near the cells to prevent the solution freezing at high altitude. This preventive action is visible in Fig. 3 with a mean pump temperature which stays close to $24{ }^{\circ} \mathrm{C}$ at high altitude. The background currents are low with a slightly higher value for the ozonesondes with $1.0 \%$ solution compared to the $0.5 \%$ solution (Fig. 1). This data set is characterized by a large variety of ozone profiles from a typical ozone hole to more conventional polar conditions; ozone column ranges are 126-423 DU.

\subsubsection{Sodankylä, Finland - balloon-borne dual- and multi-ozonesonde gondolas}

The Sodankylä station is run by the Finnish Meteorological Institute. The radiosondes used for the dual-sonde and multiple-sonde measurements were the Vaisala RS80. In the data set used here there is a mix of five dual-ozonesonde flights and four larger balloon flights with "six-sonde" payloads. The larger balloon payloads were recovered and flown again the next day with reused ozonesondes. The mean pump temperature profile shown in Fig. 3 is characterized by the leveling of pump temperature at about $22{ }^{\circ} \mathrm{C}$ due to the use of a heater in the case of the comparisons made under cold stratospheric conditions. For both the multiple- and dualozonesonde payloads a single RS80 radiosonde was applied per two ozonesondes, using interface extension boards pro- vided by ENSCI. Thus one receiving system was involved per two ozonesondes. The data set consists of

1. six pairs of EN-0.5\% and EN-1.0\% during September 2003-July 2004,

2. five pairs of EN-0.5\% and SP-1.0\% during May 2003March 2005,

3. eight pairs of EN-1.0\% and SP-1.0\% during September 2003-July 2004.

\subsubsection{Wallops Island, Virginia - balloon-borne dual-ozonesonde gondolas}

Resources for ozonesonde measurements, with Sippican radiosondes, from Wallops Island have been, and continue to be, provided by NASA Headquarters. The Wallops Island practice is to use the background current measured during the day-of-flight preparation prior to exposing the ECC to moderate ozone $(5 \mu \mathrm{A})$ for $5 \mathrm{~min}$; these backgrounds are smaller than the others shown in Fig. 1. The negative backgrounds are unusual but are included as those are what was reported in the period 1995-1999 when Wallops Island was beginning its ozone measurements. The values of $i_{o}$ are close to each other within the comparison pairs, so this difference, even if negative, has a negligible effect on the analysis which was coordinated by matching the elapsed times of flight of the two comparison systems, similar to the procedure for Payerne. The data sets consist of

1. 7 pairs of SP $5 \mathrm{~A}-\mathrm{ECC}$ $0.5 \%$ vs. $1.0 \%$ in 1996 ,

2. 11 pairs of SP 6A-ECCs $0.5 \%$ vs. $1.0 \%$ in 2004 .

\subsubsection{Laramie, Wyoming - balloon-borne multi-ozonesonde gondola}

These results were obtained from a collaboration between the Climate Monitoring and Diagnostic Laboratory (CMDL) of the National Oceanic and Atmospheric Administration and the University of Wyoming. CMDL prepared the gondola, and the University of Wyoming conducted the flight operation. The measurements were obtained from a gondola containing six EN ozonesondes, three with $0.5 \% \mathrm{KI}$ and three with $1.0 \% \mathrm{KI}$. The instruments were synchronized to a common data system and an RS80 Vaisala radiosonde. The flight occurred on 20 June 1996 and reached an altitude of $32 \mathrm{~km}$. Post-flight analysis eliminated one of the $0.5 \%$ KI EN ozonesondes from the comparison. Results from this ozonesonde were significantly different from the other two $0.5 \% \mathrm{KI}$ ozonesondes, which agreed quite well.

\subsection{Data processing}

The ozone data processing from the measured current is based on Eq. (4) with little variability among the data sets. The major difference is in the sampling frequency of the 
measurements, which ranged from 0.2 to $1.0 \mathrm{~Hz}$. The typical e-folding response of an ozonesonde is on the order of $0.05 \mathrm{~Hz}$ (Smit and Kley, 1998). All the sampling rates here are faster than this but are the same for every pairwise comparison so the sampling rate will not affect a comparison. However, since the data analysis is based on the individual pair differences, it is necessary to average the highfrequency measurements to a common timescale to avoid unduly weighting the high-frequency data relative to the lowerfrequency measurements. Ultimately the high-frequency data were averaged to a frequency of $0.2 \mathrm{~Hz}$ so that when the dataweighted means of the comparisons were calculated each comparison profile was weighted about equally.

\subsubsection{Background current $i_{0}$}

In Fig. 1, the background currents measured for the different data sets are summarized as box-and-whisker plots. For all sites except Wallops Island, these are the background currents after exposure to moderate ozone and just prior to flight. The $i_{0}$ used at Wallops Island was prior to exposure to moderate ozone on the day of flight preparations. This may explain the slightly lower backgrounds obtained at Wallops Island. The medians of $i_{0}$ from the various sites are all below $0.03 \mu \mathrm{A}$, indicating the quality and consistency of the ozonesonde preparations. The $i_{0}$ values for the $1.0 \%$ solution tend to be slightly higher than those for the $0.5 \%$ solution, suggesting the impact of the larger buffer amount (Johnson et al., 2002). Boyd et al. (1998) argue that the large difference between their ascent and descent ozone (tropospheric) profiles is attributable to an increase in the background current after exposure to high ozone concentration in the stratosphere. They have observed this increase with the $1 \%$ solution but not with the $0.5 \%$. Similarly in the laboratory preparation, the ozonesondes are exposed to high ozone levels for $10 \mathrm{~min}$, and the slightly higher $i_{0}$ values for the $1.0 \%$ solution could be related to such a memory effect. The origin of the background current is still poorly understood (Smit et al., 2007). Vömel and Diaz (2010) measured the rate at which ozonesondes approach background in the laboratory, with some implications for measurements in the tropics of very low tropospheric ozone concentrations.

\subsubsection{Pump flow rate}

The pump flow rate is the second parameter measured in the laboratory preparation of each ozonesonde. Figure 2 shows the coherency of the pump flow rates at the five field measurements sites. In about half the measurement sets, the interquartiles of the variations amongst the instruments measured are less than $3 \%$ of the median, and in all cases except one the interquartiles are less than $6 \%$ of the median. The figure also shows a systematically $0.2-0.3 \mathrm{~mL} \mathrm{~s}^{-1}$ higher flow rate for SP pumps compared to EN pumps.

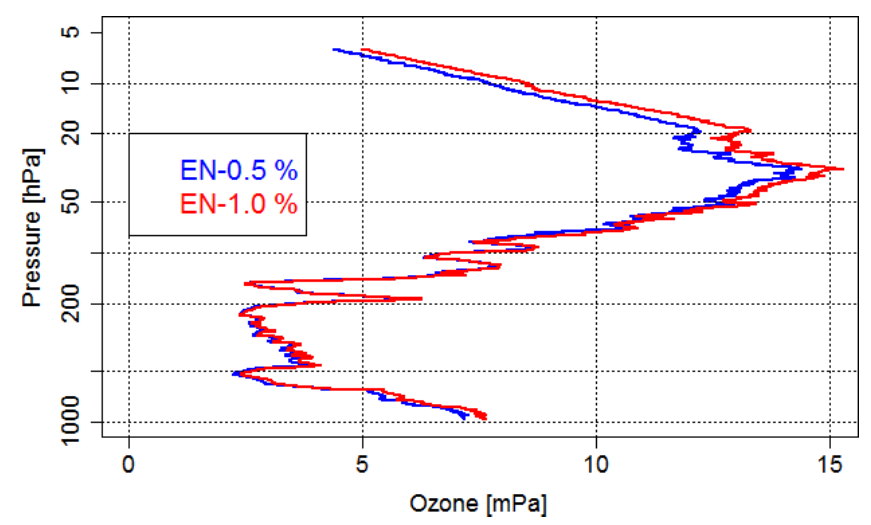

Figure 4. Example of the results of a dual-ozonesonde flight profile from Payerne. The only difference between the ozonesondes is the KI solution concentration.

\subsubsection{Pump efficiency correction}

The application of pump efficiency corrections varies amongst the data sets. In general Komhyr (1986) is used for SP and Komhyr et al. (1995a) is used for EN ozonesondes. Since the comparisons analyzed are amongst pairs of identical ozonesondes, the pump efficiency does not play an important factor unless significantly different pump efficiencies were applied separately to the ozonesondes in a measurement pair. In most cases the same efficiency factors were applied to both ozonesondes of a pair. The one exception is the Wallops Island data, where individual pump efficiency curves were applied prior to mid-2000, when the system failed. The pairwise comparisons of these data, however, were quite similar to the Wallops Island data, where identical pump efficiencies were used, and to the pairwise comparisons from the other data sets.

\subsubsection{Pump temperature}

For the data processing, individual pump temperatures are used as illustrated in Fig. 3 for the mean pump temperature profiles for each data set. It should be noted that the SP 5A ozonesondes used at Wallops Island did not have an explicit hole to insert the pump temperature sensor. The standard deviations of the temperature range from $1{ }^{\circ} \mathrm{C}$ for McMurdo Station to $5^{\circ} \mathrm{C}$ for Sodankylä. The pump temperature decrease over a profile is around $7-10^{\circ} \mathrm{C}$ for the ozonesondes with a heater and $20-23^{\circ} \mathrm{C}$ for the ozonesondes without a heater. This parameter also is reproducible within the ozonesondes pairs and thus does not impact significantly the pairwise comparisons.

\section{Comparisons of ozone partial pressure}

In Fig. 4, an example of a dual-ozonesonde flight from Payerne is illustrated. The two ozonesondes separated by a $1.5 \mathrm{~m}$ 
(a) Ensci Payerne, $\mathrm{Oz}>0.5 \mathrm{mPa}$
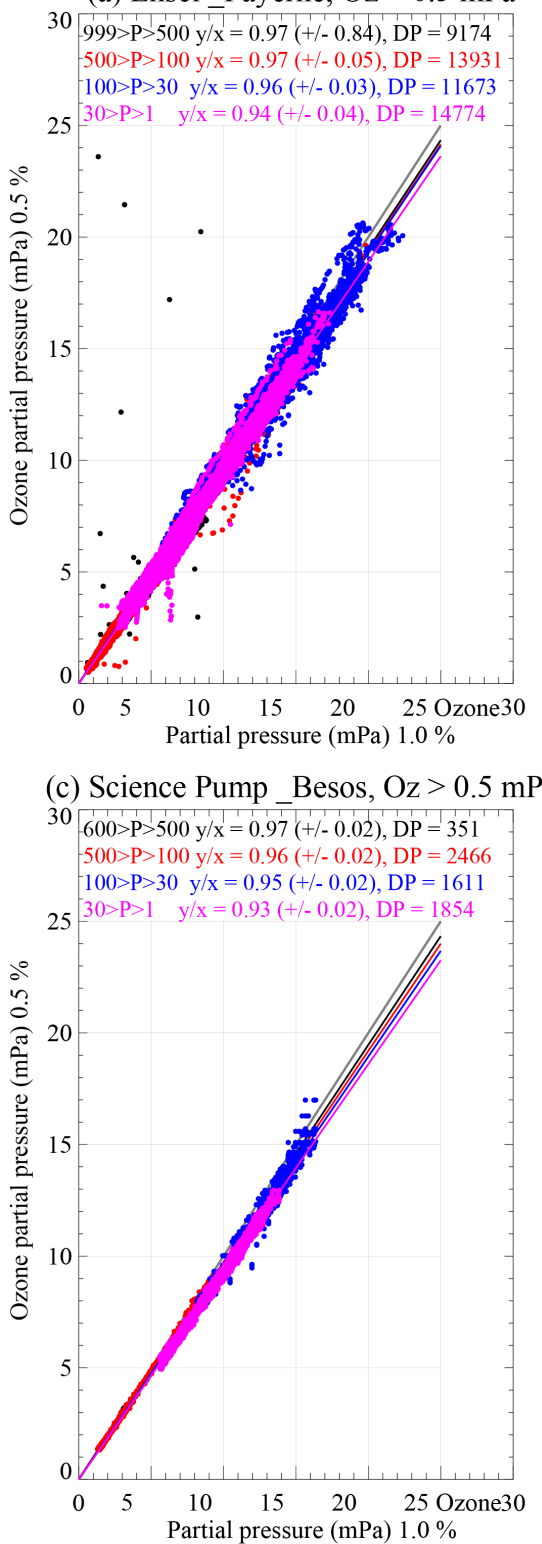

(b) Ensci McMurdo, $\mathrm{Oz}>0.5 \mathrm{mPa}$
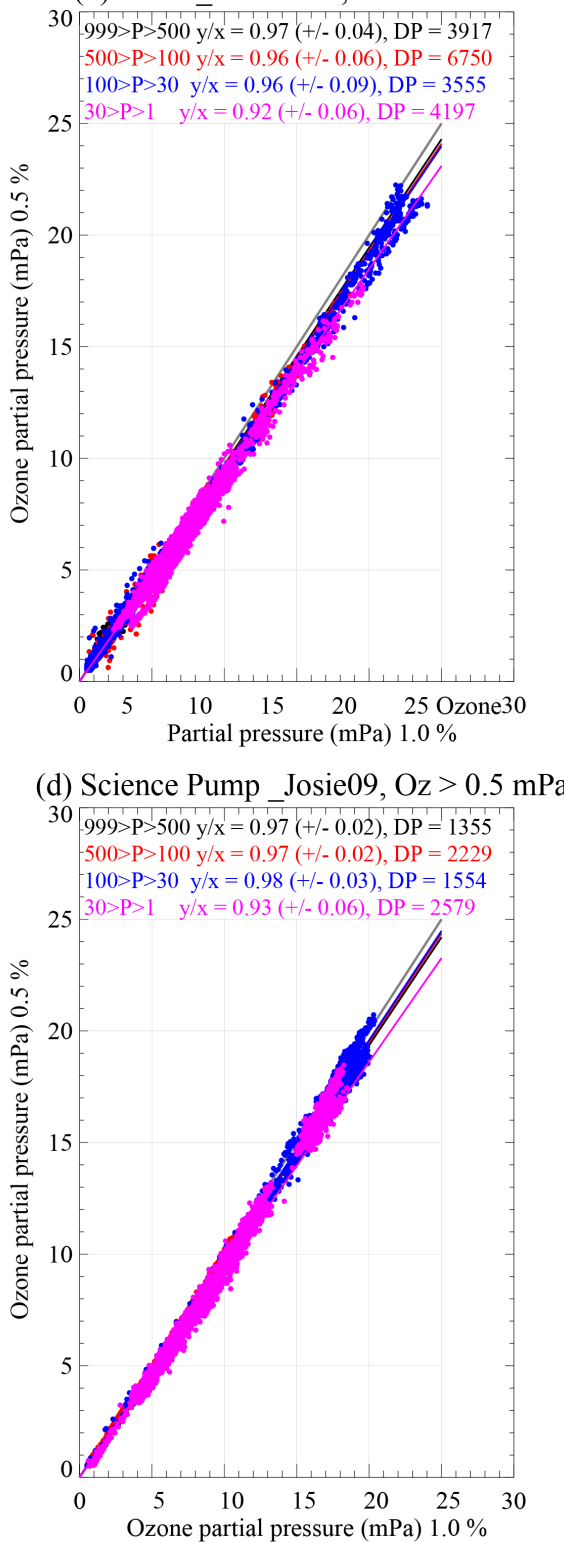

Figure 5. Scatterplots of ozone partial pressures measured with KI concentrations of $1.0 \%$ ( $x$ axis) and $0.5 \%$ ( $y$ axis) using EN ozonesondes flown from (a) Payerne and (b) McMurdo Station, and with SP ozonesondes from (c) BESOS and (d) JOSIE09. The data are subdivided into four pressure intervals, and averages and standard deviations of the ratios of $y: x$ are listed on the panels along with the number of measurements (noted as DP for data points). Only ozone measurements above $0.5 \mathrm{mPa}$ are included. At $p \geq 30 \mathrm{hPa}$ there is little variation in the ratios by pressure interval, location, or ozonesonde type. At $p<30 \mathrm{hPa}$ ratios are decreasing. The $1: 1$ line is shown in gray.

long boom were hanging under the same balloon, and the data transmitted to two independent receiving systems on the ground. The ozone profiles have identical structures, and differences increase near the ozone maximum at pressures less than $50 \mathrm{hPa}$, indicating some dependence on both ozone partial pressure and atmospheric pressure. The increased sensitivity of the $1.0 \%$ solution is clear throughout the profile.

\subsection{Differences between 1.0 and $0.5 \%$ KI cathode solutions for EN and SP ozonesondes}

The simplest way to analyze the data is to compare ozone partial pressures measured by ozonesonde pairs operated simultaneously, either in the atmosphere or in the simulation chamber. Scatterplots of ozone partial pressure measured with ECC ozonesondes with $1.0 \%$ solution ( $x$ axis) against simultaneous measurements with a $0.5 \%$ solution ( $y$ axis) 
are shown in Fig. 5 for EN ozonesondes flown from (a) Payerne and (b) McMurdo Station, and SP ozonesondes from (c) BESOS and (d) JOSIE09. The color coding distinguishes four pressure ranges to highlight the altitude (pressure) dependence. Only ozone partial pressures $>0.5 \mathrm{mPa}$ have been considered to remove large differences resulting from comparisons of small numbers near the measurement limit of the ozonesondes. Figure 5 demonstrates a near-linear relationship between the 0.5 and $1.0 \%$ ozonesonde measurements in the four pressure ranges considered, independent of the ozonesonde manufacturer. The mean and standard deviation of the measurement ratios in the various pressure intervals are given in the legends. The mean ratios are used to construct linear fits, which pass through the origin, to the measurements in each pressure range and are displayed in the figure. The mean ratios and standard deviations for all the measurements from JOSIE09, BESOS, Payerne, and McMurdo Station at the four pressure intervals are given in Table 2 . Table 2 also contains bulk fits to all data from Sodankylä, Wallops Island, and Laramie without differentiation according to pressure. Figure 5 and Table 2, boxes 1 and 2, display the remarkable consistency amongst all the data from the varied sources. Note the consistency of the mean ratios and their standard deviations from all data sources. Figure 5 and Table 2 also indicate a consistent 3-4\% underestimation of ozone from a $0.5 \% \mathrm{KI}$ solution compared to a $1.0 \%$ solution from the ground up to $30 \mathrm{hPa}$ for both $\mathrm{SP}$ and EN ozonesondes. An increase of the difference to $6-8 \%$ at pressures below $30 \mathrm{hPa}$ is also shown by the four data sets (Fig. 5).

Table 2 also shows additional analysis in three other comparison groups: boxes 3 and 4 correspond to a change of provider keeping the same concentration, and the final box, 5 , corresponds to a fit to a mix of SP- $1.0 \%$ and EN-0.5\%. The tendency of a decrease of the linear term at lower pressures is present in most data sets except for this last group, where the linear fit is not statistically different than the fits at pressures above $30 \mathrm{hPa}$. The correlation coefficients for the data are all above 0.998. There are four cases in Table 2, two in the Payerne (boxes 1 and 5) and two in the BESOS (boxes 3 and 5) data sets, with standard deviations $>0.1$. These are all in the column for pressures $>500 \mathrm{hPa}$. The origin of the large standard deviations for Payerne, EN-1.0\% vs. EN-0.5\%, probably lies in the outliers apparent in Fig. 5a at pressures $>500 \mathrm{hPa}$. Such discrepancies are less obvious in the other Payerne comparison and in the BESOS data. The cause of these larger standard deviations was not investigated further in light of small standard deviations in all data sets at pressures less than $500 \mathrm{hPa}$.

Considering the strong linear relationship of the dual measurements for the differences in concentration in the same ozonesonde type, and differences in ozonesonde type with the same sensor concentration, it is natural to simply use a single ratio to characterize the relationship of the two measurements at pressures above a certain threshold pressure and then to use a linear relationship in $\log _{10}(p)$ to fit the ratio at lower pressures, ensuring that the two systems merge at the threshold pressure. The ratio of the measurements from a single manufacturer at two cathode concentrations is illustrated in Fig. 6 as an ensemble of red dots for the same data sets as in Fig. 5. The dual-sonde flight measurements at Payerne and McMurdo Station (Fig. 6a, b) show a larger spread of the data, but the number of measurements is considerably larger and the atmospheric conditions are more diverse than in the BESOS and JOSIE experiments (Fig. 6c, d). Occasionally, individual flights from Payerne and McMurdo Station deviate from the majority of comparisons, seen as a set of points separated from the main cloud of points. These few comparisons are clear outliers compared to the majority of measurements but have not been removed from the analysis. The only limit placed on the data was to insure that each ozonesonde in a comparison pair measured ozone above $0.5 \mathrm{mPa}$.

These comparisons suggest that measurements from ozonesondes using a $1.0 \% \mathrm{KI}$ concentration in the cathode can be used to derive measurements which would have been obtained from measurements with a $0.5 \% \mathrm{KI}$ solution. To do this, measurements using the $1.0 \% \mathrm{KI}$ solution are modified using a pressure-independent ratio at pressures above some threshold pressure and a pressure-dependent ratio below the threshold pressure. Different values for the threshold pressure to switch from a single ratio to a pressure-dependent ratio were tested, but the results were not very sensitive to this value, and it has been fixed at $30 \mathrm{hPa}$.

With the threshold pressure level established, each data set was used to calculate a mean concentration ratio at $p \geq 30 \mathrm{hPa}$ and a linear, in $\log _{10}(p)$, fit at $p<30 \mathrm{hPa}$ for $p$ in units of $\mathrm{hPa}$. The results of this analysis are displayed in the upper two boxes of Table 3 for all data sets listed in Table 1. The second column provides the concentration ratio and its standard deviation for $p \geq 30 \mathrm{hPa}$; the third column provides the number of individual ozonesonde-to-ozonesonde comparisons $(N)$. Recall each data set was standardized to a sampling frequency of $0.2 \mathrm{~Hz}$ to balance the weights of the highfrequency and low-frequency data equally. Thus the number of data points represents primarily the number of individual ozonesonde-to-ozonesonde comparisons within each data set. For $p<30 \mathrm{hPa}$ columns 4,5 , and 6 list the fitting parameters providing the slope in $\log _{10}(p)$ and then the offset, corresponding to the value of the ozone concentration ratio at $1 \mathrm{hPa}$. Two offsets are listed. The first is the one used. The second offset is derived without a requirement to match the $p \geq 30 \mathrm{hPa}$ transfer function. The small differences between these two offsets reflects the fact that the function chosen is doing well in representing the data even without a fitting constraint. Column 7 provides the number of data points $(N)$ at $p<30 \mathrm{hPa}$, and column 8 the number of dual-ozonesonde measurements.

The coefficients for the transfer function representing the ratio of ozone sensed at the differing concentrations were calculated as a weighted mean and standard deviation (according to sample size) of the individual parameters given in 
Table 3. Transfer function parameters summary. The second and third columns are for $p \geq 30 \mathrm{hPa}$ providing the ratio and number of data points. Columns 4-7 are for $p<30 \mathrm{hPa}$, providing the slope of a linear fit in $\log _{10}(p)$, the offset adjusted to match the ratio at $30 \mathrm{hPa}$, the offset without constraint to the data below, and the number of data points. The offset is the value of the ratio at $p=1 \mathrm{hPa}$. The final column is the number of dual-sonde measurements for each data set for each application.

\begin{tabular}{|c|c|c|c|c|c|c|c|}
\hline Data set & Ratio, $p>30$ & $N(p>30)$ & $\begin{array}{r}\text { Slope } \\
\log _{10}(p)\end{array}$ & $\begin{array}{r}\text { Offset } \\
\text { adjusted }\end{array}$ & $\begin{array}{l}\text { Offset no } \\
\text { adjustment }\end{array}$ & $\begin{array}{r}N \\
(p<30)\end{array}$ & $\begin{array}{r}\text { No. dual } \\
\text { sondes }\end{array}$ \\
\hline \multicolumn{8}{|c|}{ EN- $0.5 \%$ to EN-1.0\% - compare solution strengths } \\
\hline JOSIE09 & $0.943 \pm 0.056$ & 1918 & -0.176 & 1.203 & 1.052 & 949 & 3 \\
\hline BESOS & $0.951 \pm 0.028$ & 5003 & 0.041 & 0.981 & 0.882 & 1854 & 9 \\
\hline Payerne & $0.965 \pm 0.546$ & 34855 & 0.031 & 0.920 & 0.910 & 14744 & 48 \\
\hline Sodankylä & $0.941 \pm 0.027$ & 2291 & 0.109 & 0.780 & 0.762 & 524 & 4 \\
\hline McMurdo & $0.977 \pm 0.124$ & 15030 & 0.118 & 0.802 & 0.785 & 4197 & 18 \\
\hline Laramie & $0.974 \pm 0.044$ & 1290 & 0.063 & 0.882 & 0.848 & 378 & 6 \\
\hline Weighted mean & $0.966 \pm 0.075$ & 60387 & 0.041 & 0.904 & 0.886 & 22676 & 88 \\
\hline \multicolumn{8}{|c|}{ SP- $0.5 \%$ to SP- $1.0 \%$ - compare solution strengths } \\
\hline JOSIE09 & $0.955 \pm 0.129$ & 1919 & -0.164 & 1.198 & 1.051 & 949 & 3 \\
\hline BESOS & $0.975 \pm 0.105$ & 5005 & 0.014 & 0.954 & 0.914 & 1854 & 9 \\
\hline Wallops I. & $0.937 \pm 0.065$ & 10123 & 0.052 & 0.860 & 0.865 & 2083 & 16 \\
\hline Weighted mean & $0.950 \pm 0.084$ & 17047 & -0.004 & 0.962 & 0.919 & 4886 & 28 \\
\hline \multicolumn{8}{|c|}{ SP- $1.0 \%$ to EN-1.0\% - compare sonde providers } \\
\hline JOSIE09 & $0.945 \pm 0.0 .074$ & 4475 & 0.133 & 0.749 & 0.744 & 2217 & 7 \\
\hline BESOS & $0.959 \pm 0.061$ & 5005 & 0.145 & 0.745 & 0.756 & 1854 & 9 \\
\hline Sodankylä & $0.963 \pm 0.026$ & 4041 & 0.112 & 0.798 & 0.784 & 961 & 8 \\
\hline Weighted mean & $0.956 \pm 0.053$ & 13521 & 0.133 & 0.757 & 0.756 & 5032 & 24 \\
\hline \multicolumn{8}{|c|}{ SP- $0.5 \%$ to EN- $0.5 \%$ - compare sonde providers } \\
\hline JOSIE09 & $0.954 \pm 0.054$ & 3193 & 0.179 & 0.690 & 0.680 & 1587 & 5 \\
\hline BESOS & $0.977 \pm 0.0 .027$ & 5003 & 0.119 & 0.801 & 0.786 & 1854 & 9 \\
\hline Weighted mean & $0.968 \pm 0.037$ & 8196 & 0.147 & 0.750 & 0.737 & 3441 & 14 \\
\hline \multicolumn{8}{|c|}{$\mathrm{SP}-1.0 \%$ to EN- $0.5 \%$ - the provider recommendations } \\
\hline JOSIE09 & $0.998 \pm 0.055$ & 1919 & 0.880 & -0.301 & 0.142 & 949 & 3 \\
\hline BESOS & $1.009 \pm 0.068$ & 5004 & 0.112 & 0.842 & 0.864 & 1854 & 9 \\
\hline Payerne & $1.008 \pm 0.251$ & 17123 & 0.065 & 0.912 & 0.927 & 7069 & 26 \\
\hline Sodankylä & $1.023 \pm 0.027$ & 2462 & 0.003 & 1.019 & 1.015 & 642 & 5 \\
\hline Weighted mean & $1.009 \pm 0.054$ & 26508 & 0.143 & 0.797 & 0.850 & 10514 & 43 \\
\hline
\end{tabular}

Table 3 for all data sets considered in the analysis. These values comprise the final row in each box in Table 3. Not all data from each data set were used due to unstable ratios at particularly low ozone concentrations, or during clearly deficient ozonesonde performance. The primary regions where some of the data were excluded are displayed as the gray areas in Fig. 6. Data in these regions were excluded for the following specific reasons:

1. McMurdo Station: some of the dual-ozonesonde measurements were completed in ozone hole conditions, and in these cases ozone drops to near zero, producing highly divergent ratios.

2. JOSIE: at three points during the simulated profiles, the ozone flow was stopped to measure the residual signal and the response time, producing very low ozone levels and thus likewise ratio divergences.

3. BESOS: in the first minutes of the flight, the data acquisition unit was unstable and too noisy to consider in the present analysis.

The common transfer function to analyze differences in $\mathrm{KI}$ concentration, $\mathrm{OZ}_{\text {conc }}$, is given in Eq. (5) and presented in Fig. 6 as a blue line for $p \geq 30 \mathrm{hPa}$ and a black line for $p<30 \mathrm{hPa}$. The function displayed in Eq. (5) accounts for a change of solution concentration independently of the ozonesonde provider.

$\frac{\mathrm{OZ}_{0.5 \%}(p)}{\mathrm{OZ}_{1.0 \%}(p)}=0.96$, for $p \geq 30 \mathrm{hPa}$, 

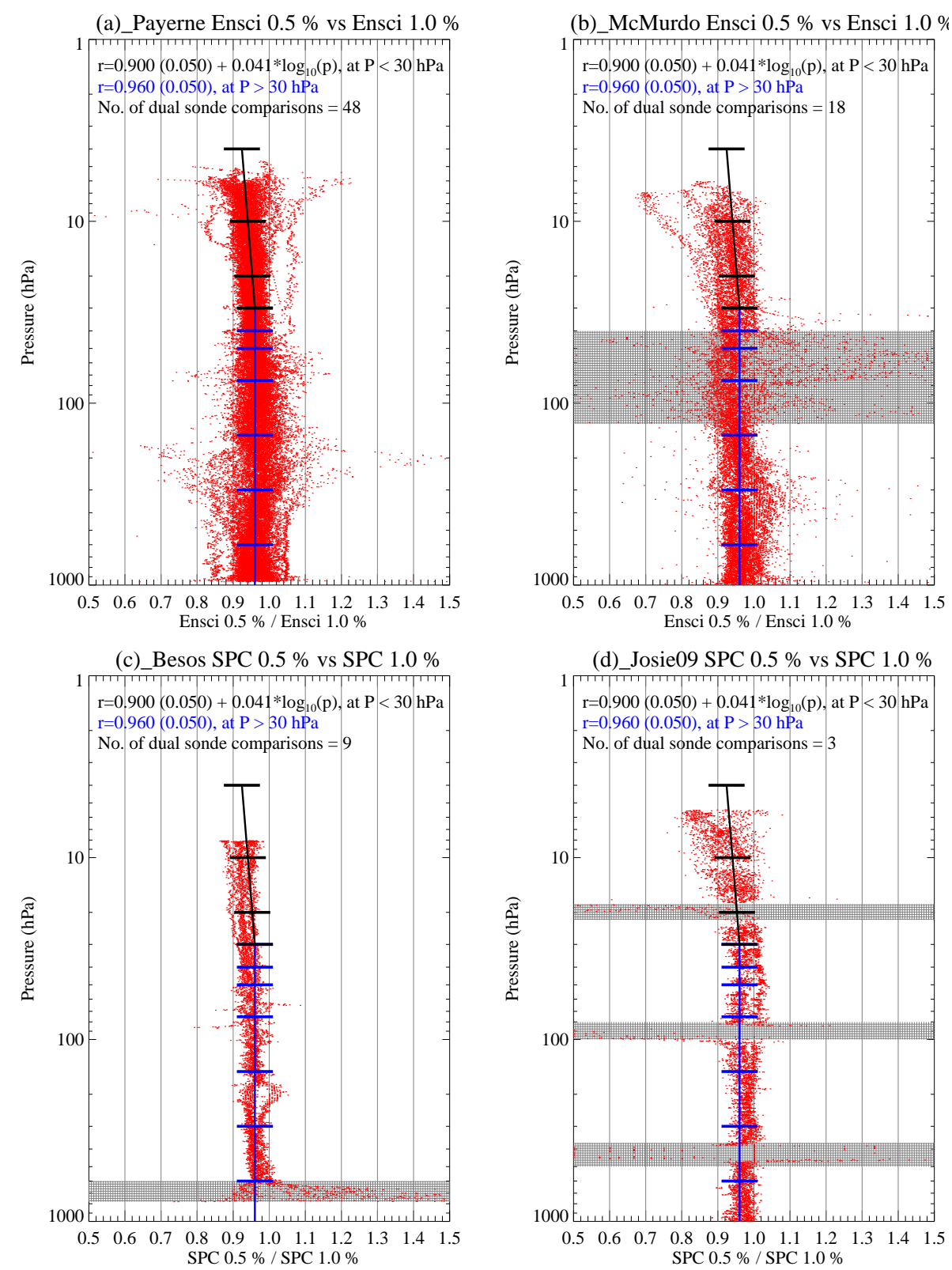

Figure 6. Vertical profiles of ratios of ozone partial pressure using ozonesondes with different KI concentrations $(0.5,1.0 \%)$ in ozonesondes of the same manufacturer, EN or SP. (a) Payerne - EN; (b) McMurdo - EN; (c) BESOS - SP; and (d) JOSIE09 - SP. The hashed areas are regions of low ozone concentration in ozone hole measurements, McMurdo; tests in the laboratory, JOSIE09; or during initial problems with the BESOS data system at the lowest altitudes. Fits to the data using the transfer functions from Eq. (5), and included at the top of each panel, are shown in blue and black. The numbers in parantheses behind each slope are the uncertainties of the fit.

$\frac{\mathrm{OZ}_{0.5 \%}(p)}{\mathrm{OZ}_{1.0 \%}(p)}=0.90+0.041 \cdot \log _{10}(p)$, for $p<30 \mathrm{hPa}$

\subsection{Difference between EN and SP with the same solution concentration}

In Fig. 7, profiles of the ratio of SP to EN ozonesondes with the same KI solution concentration are shown in the same format as Fig. 6. The upper panels show the difference between the SP and EN ozonesondes with a $1.0 \%$ solution con- centration, while the lower panels are for the $0.5 \%$ solution concentration. Figure $7 \mathrm{a}$ is from multiple dual-ozonesonde flights at Sodankylä over the period 1995-2002, while the other panels present the analysis of the JOSIE and BESOS experiments. Using these data, and following the procedure used to reconcile the two solution concentrations in the same ozonesonde provider (Sect. 4.1), the common transfer function to correct a change from one provider to the other was 

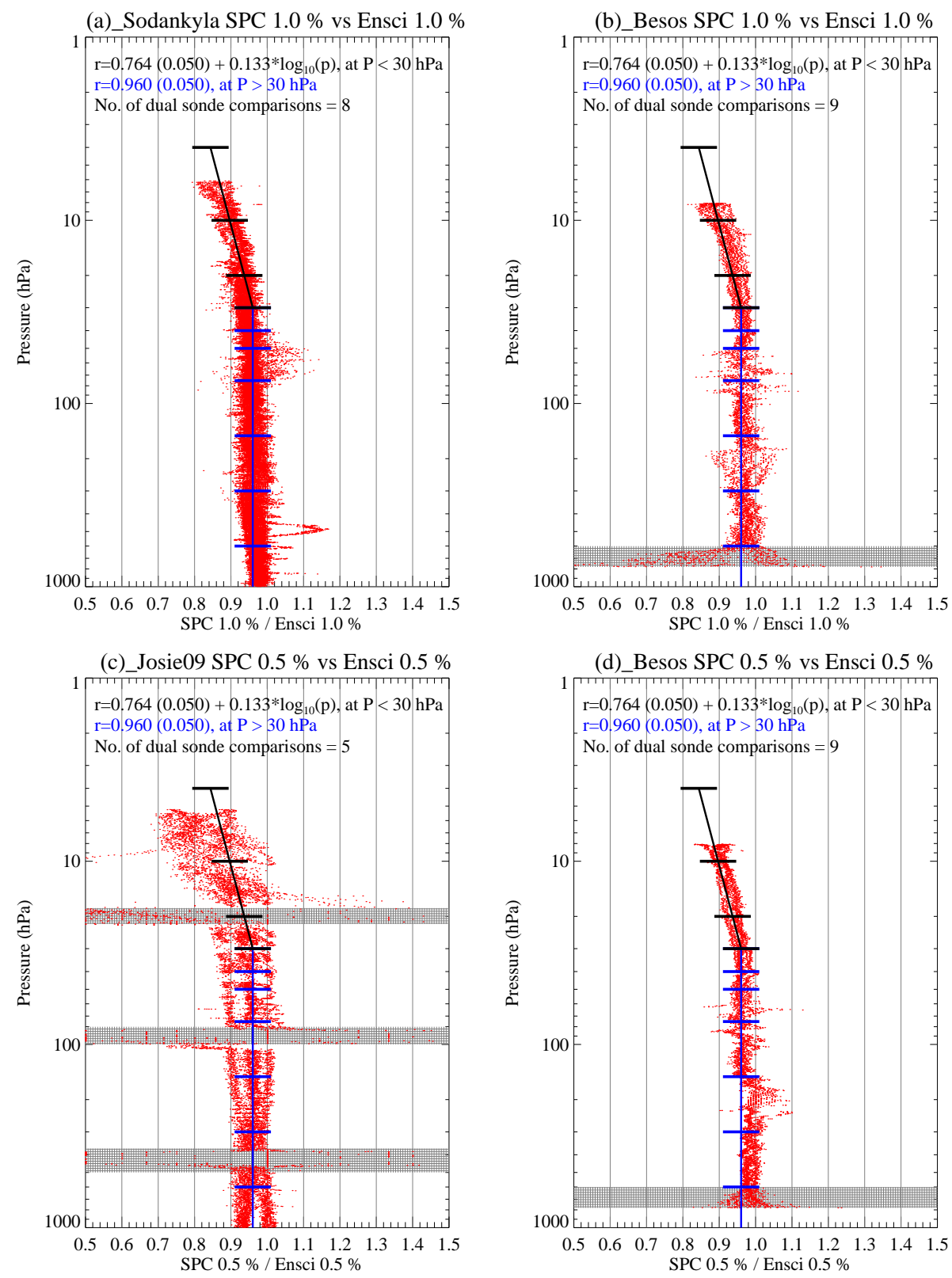

Figure 7. Vertical profiles of ratios of ozone partial pressure using ozonesondes of different manufacturer (SP, EN) with the same KI concentrations in both ozonesondes, either $1.0 \%$ (a, b) or $0.5 \%$ (c, d). (a) Sodankylä - 1.0\%; (b) BESOS - 1.0\%; (c) JOSIE09 - 0.5\%; (d) BESOS $-0.5 \%$. The hashed areas denote regions of low ozone concentration in tests in the laboratory during JOSIE09, or during initial problems with the BESOS data system. Fits to the data using the transfer functions from Eq. (6), and included at the top of each panel, are shown in blue and black. The numbers in parentheses behind each slope are the uncertainties of the fit.

derived. Similar to the analysis in Sect. 4.1 the results from fits to each data set and their weighted mean are provided in the third and fourth box in Table 3. Combining the results from the boxes comparing EN and SP ozonesondes at $1.0 \%$ and $\mathrm{EN}$ and SP ozonesondes at $0.5 \%$ results in the transfer function, $\mathrm{OZ}_{\mathrm{prov}}$, given in Eq. (6).

$\frac{\mathrm{OZ}_{\mathrm{SP}}(p)}{\mathrm{OZ}_{\mathrm{EN}}(p)}=0.96$, for $p \geq 30 \mathrm{hPa}$,
$\frac{\mathrm{OZ}_{\mathrm{SP}}(p)}{\mathrm{OZ}_{\mathrm{EN}}(p)}=0.764+0.133 \cdot \log _{10}(p)$, for $p<30 \mathrm{hPa}$

As for $\mathrm{OZ}_{\text {conc }}$, the coefficients of the transfer function $\mathrm{OZ}_{\text {prov }}$ were calculated individually for the five data sets, as was an overall mean, weighted by the number of comparisons and flights. The JOSIE data present a larger spread than in the previous case, and individual simulator runs are visible. Aside from the BESOS data for $0.5 \% \mathrm{KI}$ at $p>150 \mathrm{hPa}$ 
(Fig. 7d), where there is a tropospheric bias of $2 \%$, the $\mathrm{OZ}_{\text {prov }}$ curve reproduces the results from the different data sets. The $\log _{10}(p)$ coefficient is slightly larger in $\mathrm{OZ}_{\text {prov }}$ than in $\mathrm{OZ}_{\text {conc }}$, producing a lower value for the constant term (intercept at $1 \mathrm{hPa}$ ) since the constant ratio terms are the same (ratio $\left.\left(\mathrm{OZ}_{\text {conc }}\right)=\operatorname{ratio}\left(\mathrm{OZ}_{\text {prov }}\right)=0.96\right)$ for the $p \geq 30 \mathrm{hPa}$ domain, while the decrease in the ozone ratio between the providers increases at lower pressures comparable to the decrease in ozone ratio at differing solution concentrations (Fig. 6).

Also included in the last row in each box in Table 3 is the weighted standard deviation of the comparison ratios. These provide an indication of the uncertainty in the ratios, and thus in the corresponding transfer functions, ranging from 0.037 to 0.084 . To establish a single uncertainty which could be applied to all the transfer functions, the individual comparison standard deviations were averaged and found to be near 0.05 . Thus 0.05 was adopted as the single uncertainty which could be applied to all the transfer functions proposed. This value is used to apply the error bars shown in Figs. 6 and 7 and shows how well the transfer functions, including the uncertainty, represent the data. Clearly 0.05 both under and over estimates the ratios, depending on the particular comparison; however, over all does a reasonable job.

\subsection{Similarity between the combinations EN-0.5\% and SP-1.0 \%}

With the similarity of the two transfer functions, $\mathrm{OZ}_{\text {conc }}$ and $\mathrm{OZ}_{\text {prov }}$, it is natural to counterbalance them and compare EN ozonesondes with $0.5 \%$ solution and SP ozonesondes with $1.0 \%$ solution. The results are given in Fig. 8 for (a) Payerne, (b) Sodankylä, (c) BESOS, and (d) JOSIE09. The number of comparisons is low for JOSIE (three cases) and Sodankylä (five cases). The agreement between the ozonesonde pairs is not as clear as for the previous cases as illustrated by the Payerne data, which present a somewhat larger dispersion (10\%) in Fig. 8 than Fig. 5 (5\%). The BESOS data have a distinct behavior below and above the tropopause $(200 \mathrm{hPa})$, while the five Sodankylä flights show a constant $3 \%$ overestimation by the SP ozonesondes. While no simple transfer function is avialable to reconcile these observations, it is reassuring that the majority of the points are within $\pm 5 \%$ around 1.0 illustrated by the gray zone in Fig. 8. The last three lines of Table 3 also reveal no marked departure from unity. The gray area of $\pm 5 \%$ is the same uncertainty as used for the transfer functions, and some of the comparisons shown in Fig. 8 are better than this, but not all.

The present conclusion is that the interchange between the EN- $0.5 \%$ and SP-1.0\% combinations would not have a negative impact on the continuity of a time series. It may increase the variability, but no noticeable break should appear at the transition between these two systems.

\subsection{Transfer function application on the Nairobi data set}

The Kenyan Meteorological Department (KMD), in collaboration with MeteoSwiss, operates the Nairobi aerological station, within the SHADOZ (Southern Hemisphere ADditional OZone station) network (Thompson et al., 2012). Weekly ozone soundings began in 1996. In summer 2010, due to interruption of the Vaisala RS80 radiosonde production, new equipment based on the RS92 was installed at Nairobi. Coincidently, the ozonesonde solution concentration was changed from 1.0 to $0.5 \%$, keeping the same ozonesonde provider, $\mathrm{EN}$. This data set is used here to illustrate the application of the transfer function $\mathrm{OZ}_{\text {conc }}$ defined in Eq. (5). In Fig. 9, a time series on three pressure levels is illustrated. Color separates the measurements with the different solution concentrations. In the troposphere, the ozone partial pressure is low $(2.5 \mathrm{mPa})$ and the variability is too high to detect changes of a few percent. Therefore the $500 \mathrm{hPa}$ data illustrated in Fig. 9 do not show the change of sensor concentration. At $30 \mathrm{hPa}$, the Quasi-Biennial Oscillation is the dominant signal, and this requires at least a complete cycle after the change to correctly see the effect; however, there is a clear decrease of the mean ozone value before and after the change of concentration. Finally at $10 \mathrm{hPa}$, the lower variability and the absence of geophysical cycles in the data allow the effect of the concentration change to be clearly seen.

To quantify the concentration change, the mean ozone profiles before and after 2010 have been calculated and appear in Fig. 10, with black squares for 1996 to 2010 and blue circles after 2010. Red triangles correspond to the 1996-2010 data after correction of each profile with the transfer function $\mathrm{OZ}_{\text {conc }}$. The difference profiles are illustrated on the right side of Fig. 10 in black for the original data and in red for the corrected data for the period 1996-2010. The error bars combine the variabilities of the two original mean profiles. Even though the differences were not significant for the pressure $>30 \mathrm{hPa}$, the correction shows a net improvement for the higher levels.

For a total ozone column comparison three estimations are available for the Nairobi station: the ozonesonde integrated profile, a Dobson D018 colocated spectrophotometer, and the OMI (Ozone Monitoring Instrument) satellite overpass measurements. The change of sensing solution and the corrections shown in Fig. 10 have affected the ratios of the total column ozone as shown in Table 4.

\section{Discussion}

There has been a significant effort to reconcile ozonesonde measurements completed with instruments from the two ozonesonde providers, Science Pump and ENSCI, with various combinations of the recommendations for the KI sensor solution concentrations 1.0 and $0.5 \%$. The motivation 
(a) Payerne SPC $1.0 \%$ vs Ensci $0.5 \%$
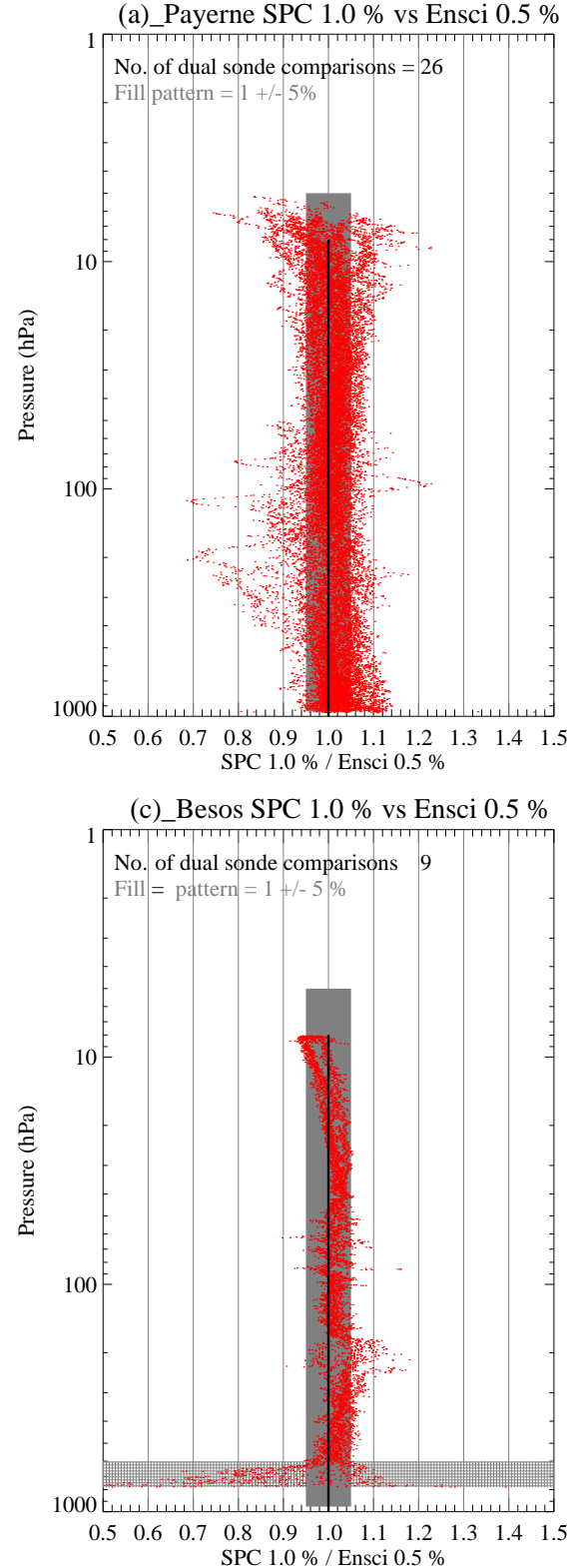

(b) Sodankyla SPC $1.0 \%$ vs Ensci $0.5 \%$
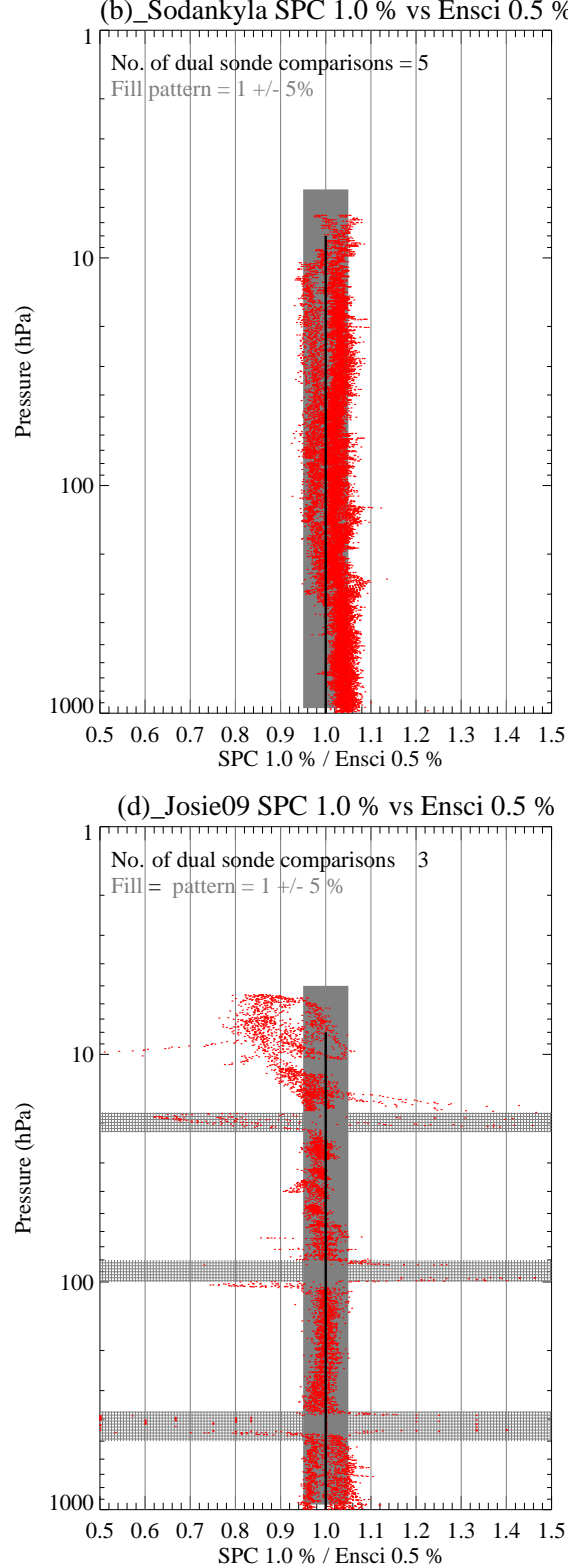

Figure 8. Ratios of SP-1.0\% to EN-0.5\% ozonesondes. The measurements are from (a) Payerne, (b) Sodankylä, (c) BESOS, and (d) JOSIE 2009. The filled regions represent $5 \%$ around 1.0. The hashed areas are as before to indicate regions of low ozone concentration during tests in JOSIE 2009 or difficulty with the data system in BESOS.

for this effort rests on characterizations of the precision and accuracy achievable with well-prepared ozonesondes through laboratory tests (Smit and Sträter, 2004a, b; Smit et al., 2007) and field tests (Kivi et al., 2007; Deshler et al., 2008). These results have shown that the precision of an ECC ozonesonde is better than observed systematic differences between ozonesonde type or solution concentration. The results presented here demonstrate that the differences in ozonesonde type, with the same solution concentration, are quite systematic and thus can be characterized, to within experimental uncertainties, with a single relationship for both
0.5 and $1.0 \%$ KI concentrations. Similarly, systematic differences between sensor solution concentrations in the same ozonesonde for both SP and EN ozonesondes can also be characterized by a single relationship. These results attest to the consistency in ozonesonde manufacturing for both companies and that both ozonesonde types have similar differences in performance when the KI solution concentration is varied, pointing again to the strength of the instrumental technique and the instruments.

The rationale employed in this analysis was to find a simple set of relationships which could be applied throughout all 
Table 4. Ratios of total column ozone at Nairobi, Kenya, measured either with the OMI satellite instrument or a Dobson spectrophotometer, compared to EN ozonesondes using 1.0 and $0.5 \% \mathrm{KI}$ concentrations. The ratios are also shown after correction of the EN-1.0\% to EN$0.5 \%\left(\mathrm{OZ}_{\mathrm{conc}}\right)$. Two approaches for the residual ozone column above the balloon burst are given: constant mixing ratio (MR) and using climatology (McPeters and Labow, 2012), the WMO recommendation.

\begin{tabular}{lrrrrrr}
\hline Ratios & $\begin{array}{r}\text { OMI/ } \\
\text { EN-1.0\% }\end{array}$ & $\begin{array}{r}\text { OMI/ } \\
\text { OZ }_{\text {conc }}\end{array}$ & $\begin{array}{r}\text { OMI/ } \\
\text { EN-0.5\% }\end{array}$ & $\begin{array}{r}\text { Dobson/ } \\
\text { EN-1.0\% }\end{array}$ & $\begin{array}{r}\text { Dobson/ } \\
\text { OZ }_{\text {conc }}\end{array}$ & $\begin{array}{r}\text { Dobson/ } \\
\text { EN-0.5\% }\end{array}$ \\
\hline Medians & 0.93 & 0.98 & 0.96 & 0.92 & 0.96 & 0.94 \\
Constant MR & \pm 0.04 & \pm 0.04 & \pm 0.04 & \pm 0.05 & \pm 0.05 & \pm 0.05 \\
\hline Medians & 0.95 & 0.98 & 0.94 & 0.92 & 0.96 & 0.92 \\
Climatology & \pm 0.03 & \pm 0.03 & \pm 0.03 & \pm 0.04 & \pm 0.04 & \pm 0.05 \\
\hline
\end{tabular}

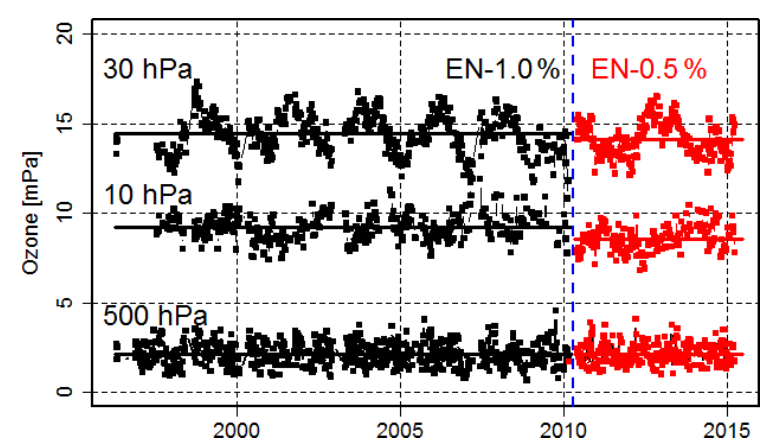

Figure 9. Ozone time series from the Nairobi station at three pressure levels: 500,30 , and $10 \mathrm{hPa}$. The black symbols correspond to the data from 1996 to 2010 (EN-1.0\% solution), and the red symbols from 2010 onwards (EN-0.5\%). The horizontal segments are the mean values over the two periods. No corrections to the EN$1.0 \%$ data have been made for this figure.

the data analyzed. Clearly there are differences in the various data sets as shown in Fig. 6. In this case the recommended relationship (Eq. 5) for the relationship between 0.5 and $1.0 \%$ KI does not optimally fit the BESOS SP data (Fig. 6c), but it does fit quite well with the Payerne and McMurdo Station data (Fig. 6a, b). The overestimation of the BESOS SP data is counterbalanced by the underestimation of the JOSIE09 SP data (Fig. 6d). This relationship does well against the BESOS EN-0.5-1.0\% and the Wallops Island SP-0.5-1.0\% comparisons (not shown). The relationship is not steep enough for the Sodankylä measurements at pressures $<30 \mathrm{hPa}$. Differences such as these led to the alternate transfer functions using first- to third-order polynomials in log pressure derived by Kivi et al. (2007) and Deshler et al. (2008). Neither of these relationships, however, would do well across the full data set analyzed here. In particular the third-order polynomial provided by Kivi et al. was required due to the significant ratio decrease at pressures below $50 \mathrm{hPa}$.

Similar comments may arise from the analysis of the ozonesonde type comparisons (Fig. 7), although in general the proposed relationship requiring a more significant decrease in the ozonesonde type ratio at pressures below $30 \mathrm{hPa}$

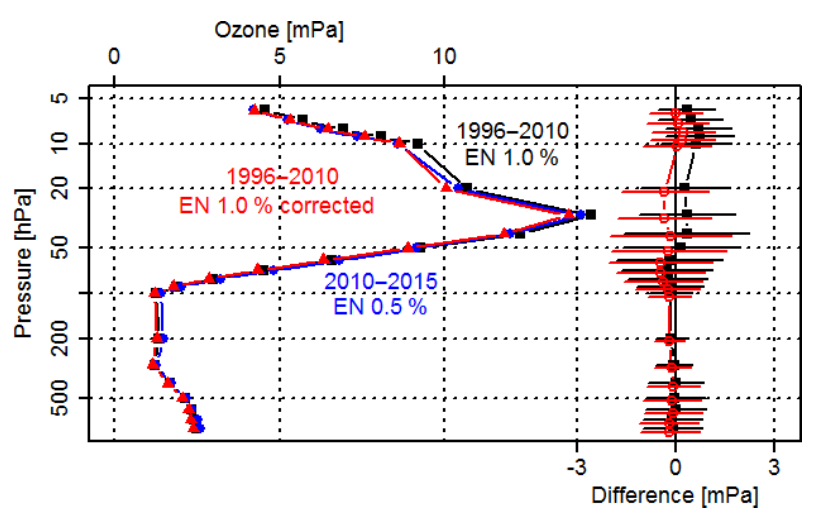

Figure 10. On the left (upper scale), mean ozone profile for the EN$1.0 \%$ period in black, EN-0.5\% period in blue, and corrected EN$1.0 \%$ profile using $\mathrm{OZ}_{\text {conc }}$ in red for the Nairobi data set. On the right (lower scale), the difference between the mean (1996-2010) ozone profiles and the mean (2010-2015) profiles before and after (black and red, respectively) correction for the change of solution concentration that occurred in 2010. A small offset of the pressure scale is used to avoid overlapping error bars.

is better at reproducing the ozonesonde type comparisons. The only data set not shown in this comparison is from JOSIE09 comparing the ozonesonde types at $1.0 \%$. That ratio profile compared to the relationships recommended is quite similar to the comparison at $0.5 \%$ (Fig. 7c).

The reasons behind the increase in ozone sensed with an increase in KI concentration have not been fully explored and are beyond the scope of this paper. The discussions of this effect have centered on the importance of the sodium phosphate hydrate buffers used to maintain the $\mathrm{pH}$ of the solution. These buffers, which vary in proportion to the KI concentration, may lead to secondary reactions between iodide ions and the buffer leading to excess iodine, thus indicating additional ozone (Saltzman and Gilbert, 1959; Johnson et al., 2002). Similarly there have been discussions on the reasons behind the increased sensitivity of the EN ozonesondes compared to SP ozonesondes. Speculation has centered on the efficiencies of the platinum electrode in scavenging the iodine, the conductance of the ion bridge, or the surface properties 
of the SP Teflon cells versus the EN molded plastic cells, but there has been no systematic investigation of this effect. This also remains beyond the scope of the work presented here.

For a transfer function to have wide acceptance within the community it must have reasonable application to the widest possible set of comparisons. Specialized transfer functions have been derived for particular subsets of the data (Kivi et al., 2007; Deshler et al., 2008), but it has not been demonstrated that these functions are useful beyond the specific data from which they were derived. The analysis here sought to develop as simple a relationship as possible based on the full comparison data set available. This was achieved through weighting of the ratio fits by the number of profile comparisons to arrive at the final four relationships described in Eqs. (5) and (6). Once derived, the individual data sets were compared against the derived transfer functions, and a subset of these is shown in Figs. 6 and 7. While Kivi et al. (2007) did not show such a comparison, Deshler et al. (2008) did. Figure 5 from Deshler et al. could be compared here against Figs. 6c, 7b, and 7d. Compared to Deshler et al. the fits proposed here improve the comparisons of ozonesonde type while not significantly diminishing the comparisons of sensor concentration. Coupling this with the ability of the fits to reproduce nearly all data sets within the uncertainty of the fits provides strong support for the validity of the proposed transfer functions. This is not to argue that the relationships proposed here should be used instead of results of an individual investigation of a particular comparison data set; however, such an individual transfer function must be supported by the appropriate measurement set and made available publicly through the refereed literature. For investigators without access to the resources to conduct such a study, the transfer functions proposed here will do an adequate job of data homogenization.

The final comparison investigated here is between the two manufacturer's recommendations. This was done through 43 comparison profiles summarized in Fig. 8. There was no attempt to derive a fitting function for these data, and as the figure illustrates such an exercise would be difficult. Figure 8 suggests some bias in the smaller data sets investigated, with ratios $>1$ for Sodankylä and BESOS but $<1$ for JOSIE09, while Payerne, by far the largest data set, shows no systematic bias. The objective analysis shown in Tables 2 and 3 not only quantifies these differences but also shows that the differences are on average generally not different than 1.0, in contrast to the results of the solution concentration and ozonesonde type comparisons. Thus the data here suggest that the two, manufacturer and WMO, recommended ozonesonde type and solution concentration packages can be used directly and should be widely comparable.

\section{Summary and conclusions}

Measurements with various combinations of ozonesonde type, Science Pump or ENSCI, and with differing combinations of the KI solution concentration, 1.0 or $0.5 \%$, have led to variations in ozonesonde preparation at a number of ozonesonde stations throughout the world. These changes began in the mid-1990s and played a role in the analysis of ozonesonde data between then and the late 2000s (Mercer et al., 2007; Tarasick et al., 2016). Recognizing that these differences exceeded the accuracy and precision that is possible from ozonesondes (Smit et al., 2007; Deshler et al., 2008) led many investigators to independently explore the differences that occur when the same ozonesonde is operated with differing solution concentrations and when differing ozonesonde types are operated with the same solution concentrations (Johnson et al., 2002; Kivi et al., 2007; Smit et al., 2007; Deshler et al., 2008). Measurements from these investigators and other unpublished comparisons have been analyzed in this paper. The analysis has focused on three basic comparisons: (1) sensor solution composition differences in ozonesondes of the same type; (2) ozonesonde type differences using the same sensor solution concentration; and (3) differences between the manufacturer and WMO recommendations, Science Pump 1.0 and ENSCI $0.5 \%$ KI solution concentrations. Using the published and unpublished data has resulted in the analysis here of 116 profile comparisons for solution concentration differences, 38 profile comparisons for ozonesonde type differences, and 43 profile comparisons of the manufacturer's solution concentration recommendations. The data sets used in the comparisons have been obtained from the laboratory (JOSIE09), multi-sonde balloon-borne gondolas (BESOS, Sodankylä), and dual-ozonesonde balloon-borne gondolas (Payerne, McMurdo Station, Sodankylä, Wallops I., Laramie), involving at least six different scientific groups.

Overall the measurements display a satisfying coherence when solution concentrations or ozonesonde type are compared. At pressures above $30 \mathrm{hPa}$, the surface to $30 \mathrm{hPa}$, the two measurements can be characterized with a simple ratio displaying almost no pressure dependence. In addition this ratio is, within experimental uncertainty, the same, 0.96, whether the difference is in solution concentration with the same ozonesonde type or ozonesonde type with the same solution concentration. Ozone concentrations are higher for $1.0 \%$ than $0.5 \% \mathrm{KI}$ and for ENSCI than Science Pump ozonesondes. At pressures below $30 \mathrm{hPa}$ there is a pressure dependence which is linear in $\log _{10}$ of pressure. This pressure dependence is more pronounced for differences in ozonesonde type. The results arrived at here are simpler than previous recommendations but are based on a much more comprehensive data set, which also includes all of the data used in deriving the previous transfer functions (Kivi et al., 2007; Deshler et al., 2008). Both of the previous transfer functions proposed used a relationship requiring a polyno- 
mial in altitude or $\log$ of the pressure for all pressures. As evidenced here, when the full data sets are investigated, the complexity of these relationships is not justified by the data.

The conclusions arrived at from the analysis described here are the following.

For differences in solution concentration independent of ozonesonde type,

$$
\begin{aligned}
& -\mathrm{OZ}_{0.5 \%}=0.96 \cdot \mathrm{OZ}_{1.0}, \text { for } p \geq 30 \mathrm{hPa} ; \\
& -\mathrm{OZ}_{0.5 \%}=\left(0.90+0.041 \cdot \log _{10}(p)\right) \cdot \mathrm{OZ}_{1.0} \%, \\
& \quad p<30 \mathrm{hPa} .
\end{aligned}
$$

For differences in ozonesonde type independent of solution concentration, but with both ozonesondes using the same solution concentration,

$$
\begin{aligned}
& -\mathrm{OZ}_{\text {SciencePump }}=0.96 \cdot \mathrm{OZ}_{\mathrm{ENSCI}} \text {, for } p \geq 30 \mathrm{hPa} \\
& -\mathrm{OZ}_{\text {SciencePump }}=\left(0.764+0.133 \cdot \log _{10}(p)\right) \cdot \mathrm{OZ}_{\mathrm{ENSCI}}, \\
& \quad \text { for } p<30 \mathrm{hPa} \text {. }
\end{aligned}
$$

We recommend that all ozonesonde measurements completed with $1.0 \% \mathrm{KI}$ in ENSCI ozonesondes or $0.5 \% \mathrm{KI}$ in Science Pump ozonesondes should adjust their data according to the relationships shown above such that the final data product would be representative of $0.5 \% \mathrm{KI}$ ENSCI or $1.0 \%$ KI Science Pump. This should be done for any data prepared for analysis and for public availability. An uncertainty of 0.05 can be ascribed to the application of these transfer functions.

The investigation of 43 profiles comparing $1.0 \% \mathrm{KI}$ in Science Pump ozonesondes and $0.5 \% \mathrm{KI}$ in ENSCI ozonesondes found that the dispersion in the comparisons was centered on a ratio of 1.0. Thus there is no recommendation to alter data obtained from instruments using the recommended concentrations.

If these recommendations are followed, it can be expected that data sets experiencing variations in the use of ozonesonde type and solution concentration will see their long-term data converge to within the expected $\pm 5 \%$ for ozonesondes and that offsets at the times of transition between the ozonesonde type, or solution concentration change, or both, will be minimized. This will improve significantly the reliability of long-term ozone measurements derived from ozone soundings and indirectly stabilize, in space and time, the long-term series of ozone measurements obtained from satellites.

These recommendations have been implemented in the WMO/GAW's guidelines for the homogenization of ozonesonde data (Smit and O3S-DQA-Panel, 2012) and recommended to the ozone sounding stations of the NDACC and SHADOZ (Thompson et al., 2012; Witte et al., 2017). The effort for the ozonesonde investigators to accomplish these corrections will be significant, but in the end the health of the network is dependent on such quality control measures being implemented, and it will greatly add to the value of the measurements. All future measurements should use the WMO/GAW recommendations for solution composition. Any deviation from these recommendations should be justified and carefully researched prior to a change.

Data availability. The ozonesonde measurements used in this analysis are available from the individual investigators, and the majority of these data are on the NDACC database. These data and the code used to create Figs. 4-8 are also compiled at ftp://cat.uwyo.edu/pub/ permanent/balloon/Manuscripts/Oz_Transfer_Functions/. The data for Figs. 9 and 10 are available on the NDACC and SHADOZ databases.

Competing interests. The authors declare that they have no conflict of interest.

Acknowledgements. This work was encouraged by the ozonesonde working groups of the WMO/GAW, NDACC, and SHADOZ. The following agencies have supported the generation of these data sets: MeteoSwiss, Finish Meteorological Institute, World Ozonesonde Calibration Facility, US National Science Foundation, US National Aeronautics and Space Administration, and US National Oceanic and Atmospheric Administration.

Edited by: H. Maring

Reviewed by: two anonymous referees

\section{References}

Barnes, R. A., Bandy, A. R., and Torres, A. L.: Electrochemical concentration cell ozonesonde accuracy and precision, J. Geophys. Res., 90, 7881-7887, 1985.

Beekmann, M., Ancellet, G., Megie, G., Smit, H., and Kley, D.: Intercomparison campaign for vertical ozone profiles including electrochemical sondes of ECC and Brewer-Mast type and a ground based UV-differential absorption lidar, J. Atmos. Chem., 19, 259-288, 1994.

Boyd, A. W., Willis, C., and Cyr, R.: New determination of stoichiometry of the iodometric method for ozone analysis at $\mathrm{pH}$ 7.0, Anal. Chem., 42, 670-672, 1970.

Boyd, I., Bodeker, G., Connor, B., Swart, D., and Brinksma, E.: An assessment of ECC ozondesondes operated using $1 \%$ and $0.5 \%$ KI cathode solutions at Lauder, New Zealand, Geophys. Res. Lett., 25, 2409-2412, 1998.

Brewer, A. W. and Milford, J. R.: The Oxford-Kew ozondesonde, P. R. Soc. Lond. A., 256, 470-495, 1960.

Calisesi, Y., Stübi, R., Kämpfer, N., and Viatte, P.: Investigation of systematic uncertainty in Brewer-Mast ozone soundings using observations from a ground-based microwave radiometer, J. Atmos. Ocean. Tech., 20, 1543-1551, 2003.

Cionni, I., Eyring, V., Lamarque, J. F., Randel, W. J., Stevenson, D. S., Wu, F., Bodeker, G. E., Shepherd, T. G., Shindell, D. T., and Waugh, D. W.: Ozone database in support of CMIP5 simulations: results and corresponding radiative forcing, Atmos. Chem. 
Phys., 11, 11267-11292, https://doi.org/10.5194/acp-11-112672011, 2011.

Davies, J., McElroy, C. T., Tarasick, D. W., and Wardle, D. I.: Ozone Capture Efficiency in ECC Ozonesondes; Measurements made in the Laboratory and during Balloon Flights, EAE03-A-13703, Geophysical Research Abstracts, Vol. 5, 13703, EGS-AGU-EUG Joint Assembly, Nice, France, 6-11 April, 2003.

Deshler, T., Mercer, J., Smit, H. G., Oltmans, S. J., Johnson, B. J., Stübi, R., Levrat, G., Davies, J., Thompson, A., Witte, J., Schmidlin, F., Brothers, G. B., Toru, S., and Proffitt, M.: Atmospheric comparison of electrochemical cell ozonesondes from different manufacturers, and with different cathode solution strengths: The Balloon Experiment on Standards for Ozonesondes, J. Geophys. Res., 113, D04307, https://doi.org/10.1029/2007JD008975, 2008.

Dietz, R. N., Pruzansky, J., and Smith, J. D.: Effect of pH on the stoichiometry of the iodometric determination of ozone, Anal. Chem., 45, 402-404, 1973.

Dobson, G. M. B., Harrison, D. N., and Lawrence, J.: Measurements of the Amount of Ozone in the Earth's Atmosphere and Its Relation to Other Geophysical Conditions, Part II, P. Roy. Soc. A, 114, 521-541, 1927.

Fioletov, V., Tarasick, D., and Petropavlovskikh, I.: Estimating ozone vari-ability and instruments uncertainties from sbuv(/2), ozonesondes, umkehr, and sage ii measurements: Short-term variations, J. Geophys. Res., 111, D02305, https://doi.org/10.1029/2005JD006340, 2006.

GCOS: Implementation Plan for the Global Climate Observing System (GCOS) in Support of the UNFCCC (2010 Update), GCOS138 (GOOS-184, GTOS-76), World Meteorological Organization, Geneva, Switzerland, 2010.

Götz, F. W. P., Meetham, A. R., and Dobson, G. M. B.: The vertical distribution of ozone in the atmosphere, P. Roy. Soc. A, 145, 416-446, 1934.

Guirlet, M., Keckhut, P., Godin, S., and Megie, G.: Description of the long-term ozone data series obtained from different instrumental techniques at a single location: The Observatory de Haute-Provence $\left(43.9^{\circ} \mathrm{N}, 5.7^{\circ} \mathrm{E}\right)$, Ann. Geophys., 18, 13251339, 2000.

Harris, N., Hudson, R., and Phillips, C.: Assessment of trends in the vertical distribution of ozone, in SPARC Rep. 1 and WMO Ozone Res. Monit. Proj. Rep. 43, World Climate Research Program, Geneva, Switzerland, 1998.

Hilsenrath, E., Hagemeyer, R., Mentall, J., Torres, A., Attmannspacher, W., Bass, A., Evans, W., Barnes, R. A., Komhyr, W., and Robbins, D.: Results from the Balloon Ozone Intercomparison Campaign (BOIC), J. Geophys. Res., 91, 13137-13,52, 1986.

Hubert, D., Lambert, J.-C., Verhoelst, T., Granville, J., Keppens, A., Baray, J.-L., Bourassa, A. E., Cortesi, U., Degenstein, D. A., Froidevaux, L., Godin-Beekmann, S., Hoppel, K. W., Johnson, B. J., Kyrölä, E., Leblanc, T., Lichtenberg, G., Marchand, M., McElroy, C. T., Murtagh, D., Nakane, H., Portafaix, T., Querel, R., Russell III, J. M., Salvador, J., Smit, H. G. J., Stebel, K., Steinbrecht, W., Strawbridge, K. B., Stübi, R., Swart, D. P. J., Taha, G., Tarasick, D. W., Thompson, A. M., Urban, J., van Gijsel, J. A. E., Van Malderen, R., von der Gathen, P., Walker, K. A., Wolfram, E., and Zawodny, J. M.: Ground-based assessment of the bias and long-term stability of 14 limb and occultation ozone profile data records, Atmos. Meas. Tech., 9, 2497-2534, https://doi.org/10.5194/amt-9-2497-2016, 2016.

Jeannet, P., Stübi, R., Levrat, G., Viatte, P., and Stähelin, J.: Ozone balloon soundings at Payerne (Switzerland): re-evaluation of the time series 1967-2002 and trend analysis, J. Geophys. Res., 112, D11302, https://doi.org/10.1029/2005JD006862, 2007.

Johnson, B. J., Oltmans, S. J., Vömel, H., Smit, H. G. J., Deshler, T., and Kroger, C.: Electrochemical concentration cell (ECC) ozonesonde pump efficiency measurements and tests on the sensitivity to ozone of buffered and unbuffered ECC sensor cathode solutions, J. Geophys. Res., 107, 4393 , https://doi.org/10.1029/2001JD000557, 2002.

Kerr, J. B., Fast, H., McElroy, C., Oltmans, S. J., Lathrop, J. A., Kyrö, E., Paukkunen, A., Claude, H., Köhler, U., Sreedharan, C., Takao, T., and Tsukagoshi, Y.: The 1991 WMO International Ozondesondes Intercomparison at Vanscoy, Canada, J. Atmos. Ocean. Tech., 32, 685-716, 1994.

Kivi, R., Kyrö, E., Turunen, T., Harris, N. R. P., von der Gathen, P., Rex, M., Andersen, S. B., and Wohltmann, I.: Ozonesonde observations in the Arctic during 19892003: Ozone variability and trends in the lower stratosphere and free troposphere, J. Geophys. Res., 112, D08306, https://doi.org/10.1029/2006JD007271, 2007.

Kobayashi, J. and Toyama, Y.: On various methods of measuring the vertical distribution of atmospheric ozone (III) - Carbon iodine type chemical ozonesonde, Pap. Met. Geophys., 17, 113126, 1966.

Komhyr, W. D.: Electrochemical concentration cells for gas analysis, Ann. Geophys., 25, 203-210, 1969.

Komhyr, W. D.: Operations handbook-ozone measurements to 40-km altitude with model 4A electrochemical concentration cell (ECC) ozonesondes (used with 1680-MHz radiosondes), in Technical memorandum ERL ARL-149, NOAA, Boulder, Colorado, 49 pp., 1986.

Komhyr, W. D. and Harris, T. B.: Note on flow rate measurements made on Mast-Brewer ozone sensor pumps, Mon. Weather Rev., 93, 267-268, 1965.

Komhyr, W. D., Barnes, R. A., Brothers, G. B., Lathrop, J. A., and Opperman, D. P.: Electrochemical concentration cell ozonesondes performance evaluation during STOIC 1989, J. Geophys. Res., 100, 9231-9244, 1995a.

Komhyr, W. D., Connor, B., Mcdermid, I., McGee, T., Parrish, A., and Margitan, J.: Comparison of STOIC 1989 ground-based lidar, microwave spectrometer, and Dobson spectrophotometer umkehr ozone profiles with ozone profiles from balloon-borne electrochemical concentration cell ozonesondes, J. Geophys. Res., 100, 9273-9282, 1995b.

Labow, G. J., McPeters, R. D., Bhartia, P. K., and Kramarova, N.: A comparison of 40 years of SBUV measurements of column ozone with data from the Dobson/Brewer network, J. Geophys. Res.Atmos., 118, 7370-7378, https://doi.org/10.1002/jgrd.50503, 2013.

Lanting, R. W.: Modification of the potassium iodide procedure for improved stoichiometry, Atmos. Environ., 13, 553-554, 1979.

Liu, X., Chance, K., Sioris, C. E., Kurosu, T. P., and Newchurch, M. J.: Intercomparison of GOME, ozonesonde, and SAGE II measurements of ozone: Demonstration of the need to homogenize available ozonesonde data sets, J. Geophys. Res., 111, 14305, https://doi.org/10.1029/2005JD006718, 2006. 
Logan, J. A., Staehelin, J., Megretskaia, I. A., Cammas, J.P., Thouret, V., Claude, H., De Backer, H., Steinbacher, M., Scheel, H.-E., Stubi, R., Fröhlich, M., and Derwent, R.: Changes in ozone over Europe: Analysis of ozone measurements from sondes, regular aircraft (MOZAIC) and alpine surface sites, J. Geophys. Res.-Atmos., 117, D09301, https://doi.org/10.1029/2011JD016952, 2012.

McPeters, R. D., and Labow, G. J.: Climatology 2011: An MLS and sonde derived ozone climatology for satellite retrieval algorithms, J. Geophys. Res., 117, D10303, https://doi.org/10.1029/2011JD017006, 2012.

Margitan, J. J., Barnes, R. A., Brothers, G. B., Butler, J., Burris, J., Connor, B. J., Fer-rare, R. A., Kerr, J. B., Komhyr, W. D., McCormick, M. P., McDermid, I. S., McElroy, C. T., McGee, T. J., Miller, A. J., Owens, M., Parrish, A. D., Parsons, C. L., Torres, A. L., Tsou, J. J., Walsh, T. D., and Whiteman, D.: Stratospheric ozone intercomparison campaign (STOIC) 1989: Overview, J. Geophys. Res., 100, 9193-9208, https://doi.org/10.1029/95JD00509, 1995.

McPeters, R. D., Hofmann, D. J., Clark, M., Flynn, L., Froidevaux, L., Gross, M., Johnson, B., Koenig, G., Liu, X., McDermid, S., McGee, T., Murcray, F., Newchurch, M. J., Oltmans, S., Parrish, A., Schnell, R., Singh, U., Tsou, J. J., Walsh, T., and Zawodny J. M.: Results from the 1995 Stratospheric Ozone Profile Intercomparison at Mauna Loa, J. Geophys. Res., 104, 30505-30514, 1999.

Meijer, Y. J., Swart, D. P. J., Allaart, M., Andersen, S. B., Bodeker, G., Boyd, I., Braa-then, G., Calisesi, Y., Claude, H., Dorokhov, V., von der Gathen, P., Gil, M., Godin-Beekmann, S., Goutail, F., Hansen, G., Karpetchko, A., Keckhut, P., Kelder, H. M., Koelemeijer, R., Kois, B., Koopman, R. M., Kopp, G., Lambert, J.C., Leblanc, T., Mc-Dermid, I. S., Pal, S., Schets, H., Stübi, R., Suortti, T., Visconti, and Yela, M.: Pole-to-pole validation of Envisat GOMOS ozone profiles using data from ground-based and balloon sonde measurements, J. Geophys. Res., 109, 23305, https://doi.org/10.1029/2004JD004834, 2004.

Mercer, J. L., Kroger, C., Nardi, B., Johnson, B. J., Chipperfield, M. P., Wood, S. W., Nichol, S. E., Santee, M. L., and Deshler, T.: Comparison of measured and modeled ozone above McMurdo Station, Antarctica, 1989-2003, during austral winter/spring, J. Geophys. Res., 112, D19307, https://doi.org/10.1029/2006JD007982, 2007.

Moreira, L., Hocke, K., Eckert, E., von Clarmann, T., and Kämpfer, N.: Trend analysis of the 20-year time series of stratospheric ozone profiles observed by the GROMOS microwave radiometer at Bern, Atmos. Chem. Phys., 15, 10999-11009, https://doi.org/10.5194/acp-15-10999-2015, 2015.

Petropavlovskikh, I., Bhartia, P. K., and DeLuisi, J.: New Umkehr ozone profile retrieval algorithm optimized for climatological studies, Geophys. Res. Lett., 32, L16808, https://doi.org/10.1029/2005GL023323, 2005.

Pitts Jr., J. N., McAfee, J. M., Long, W. D., and Winer, A. M.: Long-path infrared spectroscopic investigation at ambient concentrations of the $2 \%$ neutral buffered potassium iodide method for determination of ozone, Environ. Sci. Technol., 10, 787-793, 1976.

Proffitt, M. H. and McLaughlin, R. J.: Fast dual-beam uv-absorption photometer suitable for use on stratospheric balloons, Rev. Sci. Instrum., 54, 1719-1728, 1983.
Saltzman, B. E. and Gilbert, N.: Iodometric microdetermination of organic oxidants and ozone, resolution of mixtures by kinetic colorimetry, Anal. Chem., 31, 1914-1920, 1959.

Smit, H. G. J. and Kley, D.: The 1996 WMO international intercomparison of ozonesondes under quasi flight conditions in the environmental simulation chamber at Jülich, in WMO Global Atmospheric Watch Report, 130, World Meteorological Organization, Geneva, 1998.

Smit, H. G. J. and Sträter, W.: JOSIE-1998 performance of the ECC ozondesondes of SP-6A and ENSCI-Z type, in WMO Global Atmospheric Watch Report, 157, World Meteorological Organization, Geneva, 2004a.

Smit, H. G. J. and the ASOPOS panel (Assessment of Standard Operating Procedures for Ozonesondes): Quality assurance and quality control for ozonesonde measurements in GAW, World Meteorological Organization, GAW Report \#201, Geneva, Switzerland, available at: http://www.wmo.int/pages/prog/arep/ gaw/documents/FINAL_GAW_201_Oct_2014.pdf (last access: 4 June 2017), 2014.

Smit, H. G. J. and the O3S-DQA-Panel (Ozone Sonde Data Quality Assessment): Guidelines for homogenization of ozonesonde data, SI2N/O3S-DQA activity as part of "Past changes in the vertical distribution of ozone assessment", available at: http: //www-das.uwyo.edu/ deshler/NDACC_O3Sondes/O3s_DQA/ O3S-DQA-GuidelinesHomogenization-V2-19November2012. pdf (last access: 4 June 2017), 2012.

Smit, H. G. J. and Sträter, W.: The 2000 WMO international intercomparison of operating procedures for ECC-ozondesondes at the environmental simulation facility at Jülich, in WMO Global Atmospheric Watch Report, 158, World Meteorological Organization, Geneva, 2004b.

Smit, H. G. J., Sträter, W., Johnson, B. J., Oltmans, S. J., Davies, J., Hoegger, B., Stübi, R., Schmidlin, F., Witte, J., Thompson, A., Boyd, I., and Poisny, F.: Assessment of the performance of ECC-ozondesondes under quasi-flight conditions in the environmental simulation chamber: Insights from the Jülich Ozondesonde Intercomparison Experiment (JOSIE), J. Geophys. Res., 112, D19306, https://doi.org/10.1029/2006JD007308, 2007.

SPARC: Trends in the Vertical Distribution of Ozone, edited by: Harris, N., Hudson, R., and Phillips, C., WMO Ozone Research and Monitoring Project Report No. 43, SPARC Report No. 1, 1998.

Staufer, J., Staehelin, J., Stübi, R., Peter, T., Tummon, F., and Thouret, V.: Trajectory matching of ozonesondes and MOZAIC measurements in the UTLS - Part 1: Method description and application at Payerne, Switzerland, Atmos. Meas. Tech., 6, 33933406, https://doi.org/10.5194/amt-6-3393-2013, 2013.

Staufer, J., Staehelin, J., Stübi, R., Peter, T., Tummon, F., and Thouret, V.: Trajectory matching of ozonesondes and MOZAIC measurements in the UTLS - Part 2: Application to the global ozonesonde network, Atmos. Meas. Tech., 7, 241-266, https://doi.org/10.5194/amt-7-241-2014, 2014.

Stähelin, J., Harris, N. R. P., Appenzeller, C., and Eberhard, J.: Ozone trends: a review, Rev. Geophys., 32, 231-290, 2001.

Stein, A. F., Lamb, D., and Draxler, R. R.: Incorporation of detailed chemistry into a three dimensional Lagrangian-Eulerian hybrid model: Application to regional tropospheric ozone, Atmos. Environ., 34, 4361-4372, 2000. 
Stübi, R., Levrat, G., Hoegger, B., Viatte, P., Staehelin, J., and Schmidlin, F. J.: Inflight comparison of Brewer-Mast and electrochemical concentration cell ozonesondes, J. Geophys. Res., 113, D13302, https://doi.org/10.1029/2007JD009091, 2008.

Tarasick, D. W., Davies, J., Smit, H. G. J., and Oltmans, S. J.: A re-evaluated Canadian ozonesonde record: measurements of the vertical distribution of ozone over Canada from 1966 to 2013, Atmos. Meas. Tech., 9, 195-214, https://doi.org/10.5194/amt-9195-2016, 2016.

Thompson, A. M., Miller, S. K., Tilmes, S., Kollonige, D. W., Witte, J. C., Oltmans, S. J., Johnson, B. J., Fujiwara, M., Schmidlin, F. J., Coetzee, G. J. R., Komala, N., Maata, M., bt Mohamad, M., Nguyo, J., Mutai, C., Ogino, S.-Y., Raimundo Da Silva, F., Paes Leme, N. M., Posny, F., Scheele, R., Selkirk, H. B., Shiotani, M., Stübi, R., Levrat, G., Calpini, B., Thouret, V., Tsuruta, H., Valverde Canossa, J., Vömel, H., Yonemura, S., Andrés Diaz, J., Tan, N. T., Thanh, and Thuy Ha, H. T.: Southern Hemisphere Additional Ozonesondes (SHADOZ) ozone climatology (2005-2009): Tropospheric and tropical tropopause layer (TTL) profiles with comparisons to OMI-based ozone products, J. Geophys. Res., 117, D23301, https://doi.org/10.1029/2011JD016911, 2012.

Thornton, D. C. and Niazy, N.: Source of background current in ECC ozondesonde: Implication for total ozone measurements, J. Geophys. Res., 87, 8943-8950, 1982.

Thornton, D. C. and Niazy, N.: Effects of solution mass transport on the ECC ozonesonde background current, Geophys. Res. Lett., 10, 148-151, 1983.

Thouret, V., Marenco, A., Logan, J. A., Nedelec, P., and Grouhel, C.: Comparisons of ozone measurements from the MOZAIC airborne program and the ozone sounding network at eight locations, J. Geophys. Res. 103, 25695-25720, https://doi.org/10.1029/98JD02243, 1998.
Thouret, V., Cammas, J.-P., Sauvage, B., Athier, G., Zbinden, R., Nédélec, P., Simon, P., and Karcher, F.: Tropopause referenced ozone climatology and inter-annual variability (1994-2003) from the MOZAIC programme, Atmos. Chem. Phys., 6, 1033-1051, https://doi.org/10.5194/acp-6-1033-2006, 2006.

Vömel, H. and Diaz, K.: Ozone sonde cell current measurements and implications for observations of near-zero ozone concentrations in the tropical upper troposphere, Atmos. Meas. Tech., 3, 495-505, https://doi.org/10.5194/amt-3-495-2010, 2010.

Witte, J. C., Thompson, A. M., Smit, H. G. J., Fujiwara, M., Posny, F., Coetzee, G. J. R., Northam, E. T., Johnson, B. J., Sterling, C. W., Mohammed, M., Ogino, S.-Y., Jordan, A., and da Silva, F. R.: First reprocessing of Southern Hemisphere ADditional OZonesondes (SHADOZ) profile records (19982015): 1. Methodology and evaluation, J. Geophys. Res. Atmos., 122, https://doi.org/10.1002/2016JD026403, 2017.

WMO: SPARC-IOC-GAW Assessment of Trends in the Vertical Distribution of Ozone, SPARC report No.1, WMO Global Ozone Research and Monitoring Project, Report No. 43, Geneva, Switzerland, May, 1998.

WMO: Scientific Assessment of Ozone Depletion: 2010, Global Ozone Research and Monitoring Project-Report No. 52, 516 pp., Geneva, Switzerland, 2010.

WMO: Scientific Assessment of Ozone Depletion: 2014, Global Ozone Research and Monitoring Project-Report No. 55, 416 pp., Geneva, Switzerland, 2014. 